\title{
استلهام التراث في شعر صلاح جرّار - ديوان "في طريقي إليك" نموذجًا
}

\section{Inspiring heritage in the poetry of Salah Jarrar: 'Fi țari:qi Pilayk' as a model}

ظاهر محمد الزواهرة

\begin{tabular}{|c|}
\hline 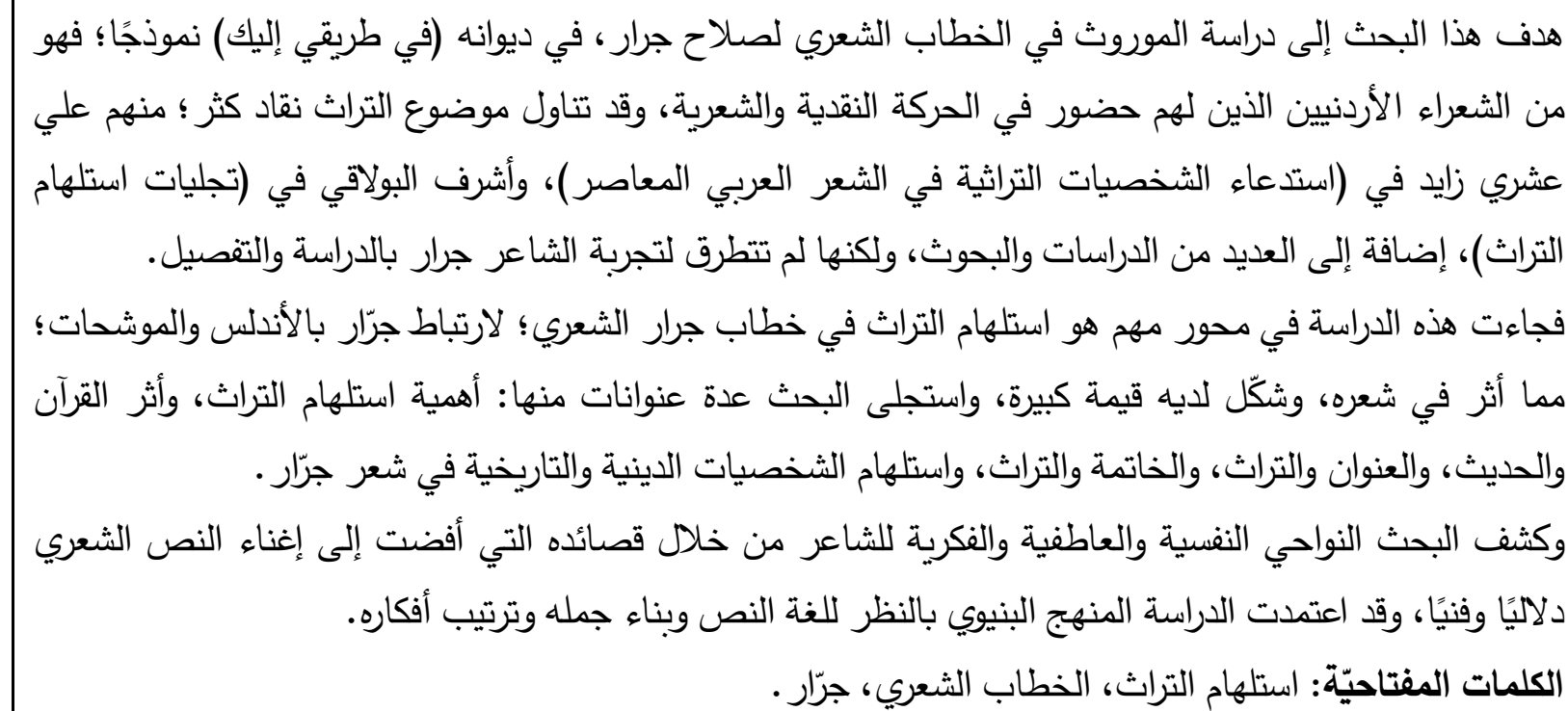 \\
\hline
\end{tabular}

\section{Abstract}

This research aims at studying the poetic heritage in the poetic discourse of Salah Jarrar, in his collection (On My Path to You) as a model. He is a prominent Jordanian poet who has influenced the critical and poetic movement. The topic of heritage has been addressed by many critics such as Ali Ashry Zayed in his "Summoning the heritage figures in the Contemporary Arabic Poetry", and Ashraf Al-Bulaqi in "Manifestations of the Inspiration of Heritage", in addition to many studies and research papers, but they have not addressed his poetic experience in detail.

The present study looked into an important theme: the inspiration of poetic heritage in Jarrar's poetic discourse due to his intimate linkage with Andalusia and Muwashahat, which influenced his poetry and formed a great value for it. The research also explored several titles, including: the importance of inspiring heritage, the impact of Qur'an and Hadith, the title and the heritage, the conclusion and the heritage, and the inspiration of religious and historical figures in Jarrar's poetry.

The research revealed the psychological, emotional and intellectual aspects of the poet through his poems that led to the semantic and artistic enrichment of the poetic text. The study adopted the structural approach by examining the language of the text, structure of its sentences and arrangement of its ideas.

Key Words: Heritage Inspiration, Poetic Discourse, Jarrar 


\section{المقدمة}

يعد استلهام التراث في الخطاب الشعري عند الثعراء من القضايا التي شغلت اهتمام النقاد، وقد تباينت الآراء والمواقف تجاه التجربة الثعرية الجديدة المعاصرة، فبعض النقاد يرى في التجربة الثعرية الحداثية خروجًا على عمود الشعر والتكر للتراث، وبعضهم يرى فيها تجربة إنسانية تعكس واقع الإنسان المعاصر، وما يؤثر فيه من عوامل اجتماعية واقتصادية وسياسية مختلفة.

ولم تتنكر التجربة الشعرية المعاصرة للتراث؛ بل عملت على إحيائه وتثبّت جذوره وتأصيله، لا إلى هدمه، وتهدف إلى دراسة جديدة للتراث على أسس جمالية فنية يمكن الأخذ بها في ظل المعاصرة، إذ لا تخلو أغلب دواوين الثعراء المعاصرين من توظيف التراث في صيغ وصور شعرية جمالية متعددة، تسقط الماضي على الحاضر من خلا إبراز القيم الإنسانية للتراث، وتقديمه في صورة جديدة، ربما تهدف إلى التحرر من بعض القيود العروضية، وتفسح الدجال للدفق الثعوري والتعبير عن الواقع من خلال رؤية إنسانية حية ومعاصرة، وبيان معاناة الإنسان في غربته بعيدًا عن وطنه، واغترابه داخل الوطن.

لقد سعى الشعراء المحدثون إلى إعادة قراءة التراث بوقائعه وشخوصه؛ للكثف عن كنوزه، وإبراز ما فيه من قيم فكرية وفنية صالحة للبقاء والاستمرار، إذ" إنه لا نجاة لشعرنا من الهوة التي انحدرت إليها بغير ربطه بتراثه العريق"(1)، كما تفاعل الشعراء مع التراث واعتمدوا عليه مادة يغْنون بها نصوصهم من الثعر أو الثخصيات الدينية

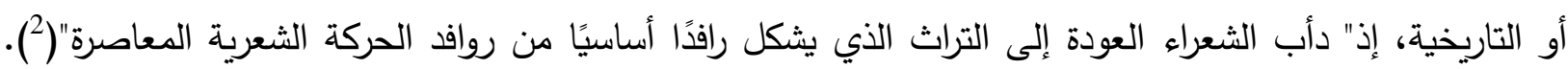
وعندما عاد الثعراء إلى التراث كان لابد من عودة حقيقية ذات قيمة لا تعتتي بالتكرار أو التقليد أو المحاكاة بل بل دون "أخضعوه لتجاربهم في قراءة جديدة لنص جديد آخر غير النص الذي هو محور التعالق"(3). إنَّ الدراسات التي تتاولت موضوع التراث كثيرة، وما تمحور عن قضية التأثر والتأثير، واستلهام التراث، والتتاص، ومنها لا الحصر : محمد مفتاح، تحليل الخطاب الثعري، استراتيجية التناص، الدار البيضاء، المركز الثقافي العربي، بيروت، دار التتوير، ط1، 1985، وهي دراسة مهمة تقدم التتاص والتعالق الثقافي بين النصوص إلى القارئ،

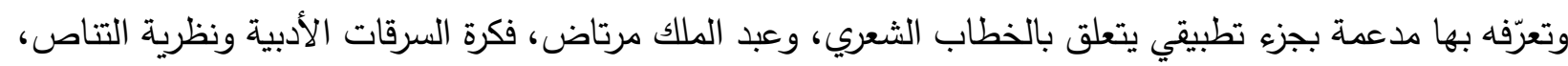

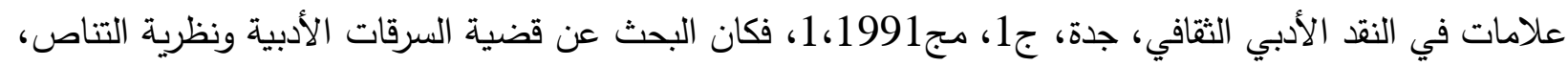
وعلي عشري زايد، استدعاء الثخصيات التراثية في الثعر المعاصر، 1997، وهو يركز على الثخصيات الموظفة في النصوص الأدبية سواء أكانت تاريخية أو أدبية أو دينية، ولم يعنَ بغير الثخصيات كثيرًا. وجاءت هذه الدراسة تستكمل ذلك البناء، وحاجةً لتناول تجربة الثاعر الناقد صلاح جرار4، وفي ديوانه" في طريقي إليك" الصادر عن الآن ناشرون وموزعون، عمان(2017)، ط1؛ إذ تحتاج التجربة الثعرية عند النقاد/ الثعراء

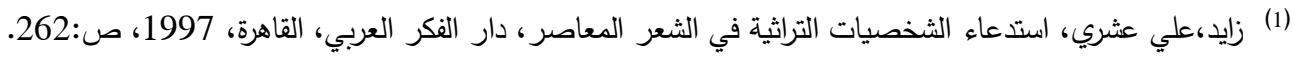

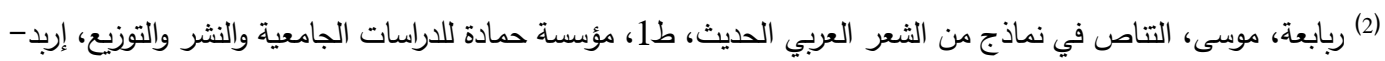
الأردن،2000،ص:11.

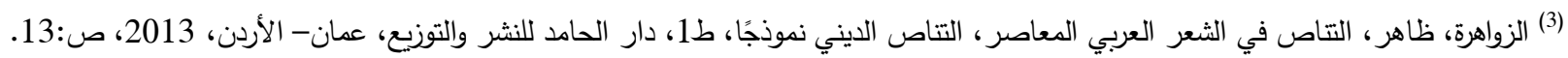

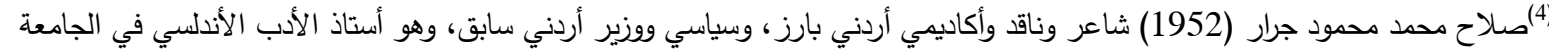

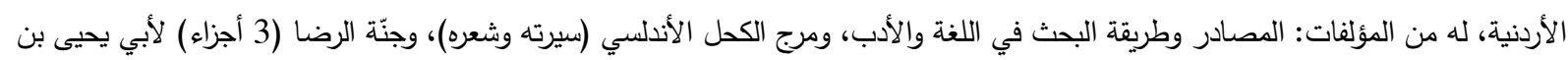


الأردنيين مزيدًا من الدراسة والتقصي، كما تهدف للكثف عن جوانب استلهام التراث من نصوص شعرية أو شخصيات تراثية أو أدبية أو دينية عند جرار في ديوانه، وكيف وظّفها في نصه الشعري؟ وما القيمة الفنية والإضافة لهذا التوظيف؟ وقد اعتمد الباحث المنهج البنيوي في استجلاء العناصر التي يتثكل منها النص؛ أي النظر إلى لغته وكيفية بناء جمله وترتيب أفكاره، وقسمت الدراسة إلى ثلاثة عناوين رئيسة، وهي: أهمية استلهام التراث في الخطاب الثعري المعاصر ، والرافد الديني في شعر صلاح جرار، والرافد الأدبي والتاريخي في شعر صلاح جرار، وإلى خمسة عناوين فرعية، وهي: أثر القرآن الكريم والحديث في شعره، واستلهام الشخصيات الدينية والتاريخية في شعره، وأثر الموروث الثعري القديم في شعره، والعنوان والموروث في شعره، والخاتمة والموروث في شعره.

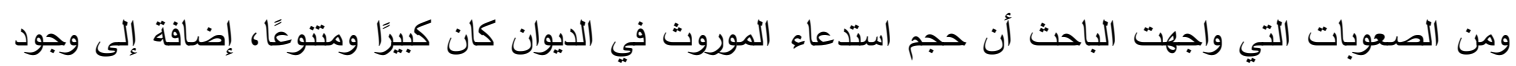

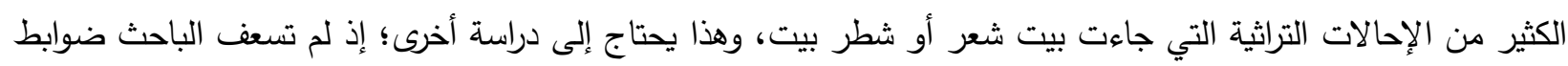
النشر المحددة لعدد الكلمات.

\section{أهمية استلهام التراث في الخطاب الثعري المعاصر}

يرتبط الأدب بعلاقات متثابكة، تمثل نسيجًا متماسكًا، وهو الأمر الذي يحتاج إلى تحليل وتذوق للوصول إلى قيمة

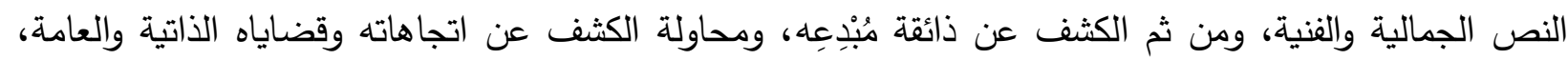
والعلاقة التي تجمع النصوص حقيقية قد لا يكون فيها شك" وهي تستمد من تراث وثقافة، ويمدها كلُ كاتب من فكره

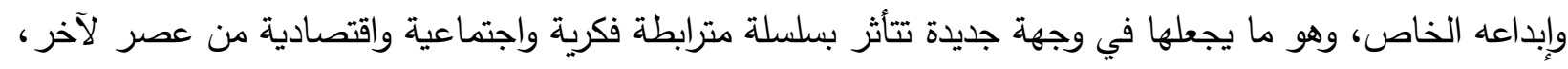

وهو ما تقتضيه ضرورة العصر المتغير"(5). إنَّ ظاهرة استلهام التراث من أبرز الظواهر الفنية في الثعر ، ولها تأثيرها الكبير في التشكيل الجمالي على التى النص الأدبي، وتضرب جذورها في عمق الماضي، و"اكتشاف الماضي أو قراءاته في ضوه الحاضر وإعادة تثكيله من جديد وفق رؤيا شعرية تمتص المحولات الدلالية الموروثة؛ لتكثف عن طزاجة التجربة الشعرية وخصوصية مبدعها

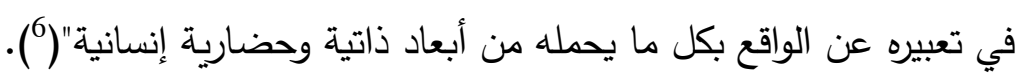

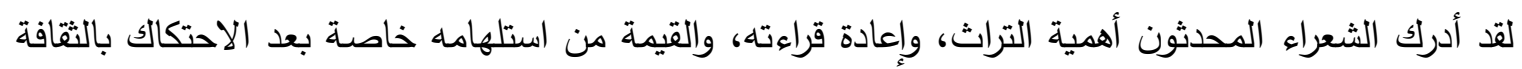
الأجنبية، وما أحدثت من تأثير عميق وقوي في أدبهم، ف" التراث منجم طاقات إيحائية لا ينفد له عطاء، فعناصره

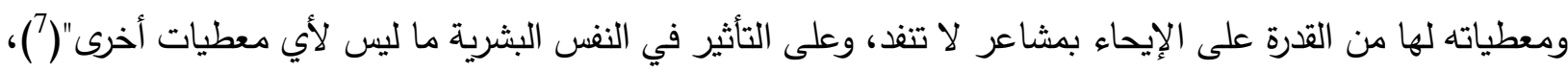
فكان التراث بكل مكوناته وآليات توظيفه قيمة فكرية وفنية وإبداعية، تكمن في اختيار شخصيات الإتهاء التراث ورموزه وأحداثه، كما أنَّ التراث أصبح ملهمًا وركيزة مهمة لدى الثعراء المحدثين، إذ" أصبح التراث الإنساني لاى الثاعر المعاصر

عاصم (تحقيق ودراسة)، وديوان الحمراء (الأشعار المنقوشة على جدران الحمراء)، وأدباء مالقه لابن خميس (تحقيق ودراسة)، وجمهرة توقيعات العرب،

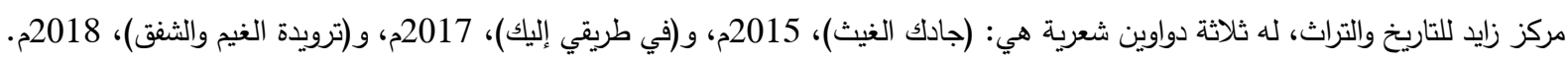

$$
\text { (5) الزواهرة، ظاهر ، التتاص في الثعر العربي المعاصر ، سابق، ص:24. }
$$

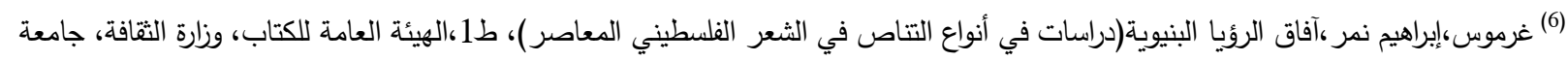

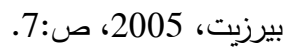

(7) بوعيشة، بوعمارة، الثاعر العربي المعاصر ومثاقفة التراث، مجلة كلية الآداب واللغات، بسكرة، العدد12011،8، ص:15. 
جانبًا من تكوينه الثعري، ذلك أنَّ تجربة الثاعر هي محاولة جاهدة لاستيعاب الوجدان الإنساني عامة من خلال إطار حضارة العصر ، وتحديد موقف الثاعر منه كإنسان معاصر "(") وتكمن أهمية استلهام التراث وتوظيفه في نصوص الثاعر المعاصر في أنه يمنح النص الشعري "عراقة وأصالة، ويمثل نوعًا من امتداد الماضي إلى الحاضر ، وتغلغل الحاضر بجذوره في تربة الماضي الخصبة، كما أنَّه يمنح الرؤية الثعرية نوعًا من الثمول والكلية"(9)، فإعادة النظر في التراث وتوظيفه في النصوص الثعرية لدى الثعراء يمنح النص قيمة ذاتية وإنسانية، حين يصل الثاعر بنصه إلى تخليد مواطن التراث في تلك النماذج القديمة من خلال ربط الماضي بالحاضر • ماضع

وعندما يشكل التراث جذور الثاعر المبدع فإنَّ توظيفه للتراث يبدو غذاء روحه، ومصدر إلهامه، وعندئذ تكون غاية إبداع الثاعر في قيمة التوظيف، وحسن الاختيار للنصوص أو الثخصيات ف" التراث هو جذور الفنان الممتدة في الأرض، والفنان الذي يعرف تراثه يقف معلقًا بين السماء والأرض، التراث عنده هو ما يجد فيه غذاء روحه ونبع

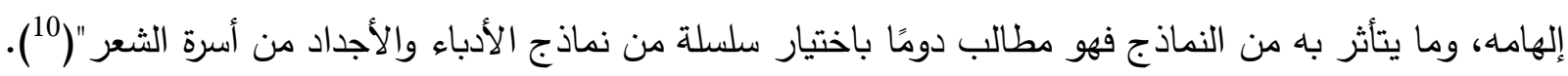

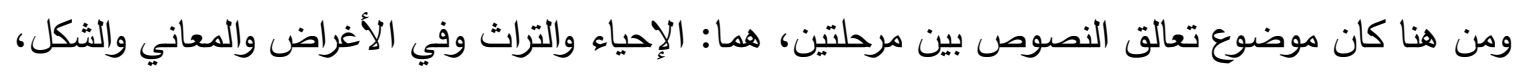
وما كان عليه بناء القصيدة الإحيائية، وتأثرها ببناء القصيدة القديمة، هو انطلاق وانفتاح بين أدب العصور ، وهو امتداد

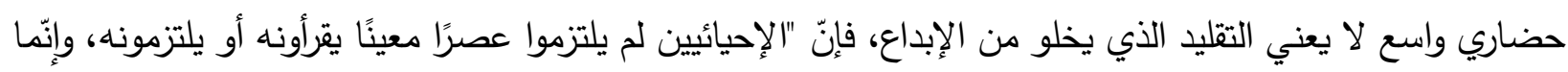

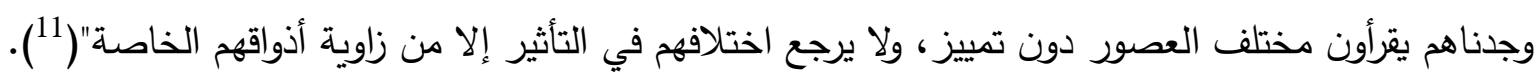

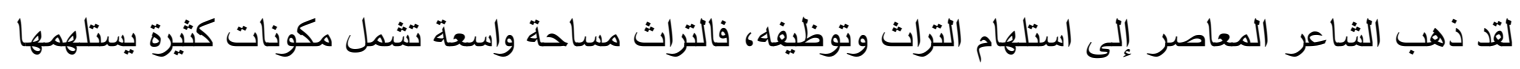
الثاعر في نصه لغاية من غايات كثيرة؛ وليحقق من خلالها إبداعه الخاص، و"وجوه التعامل مع التراث متعددة منها:

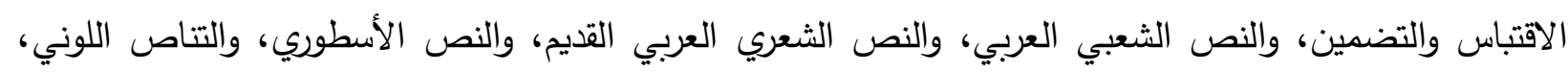

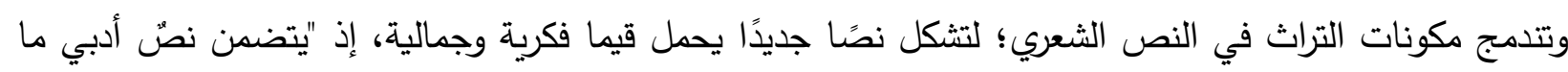
نصوصًا أو أفكارًا سابقة عليه عن طريق الاقتباس أو التضمين أو التلميح أو الإشارة أو ما شابه ذلك من المقروء الثقافي لدى الأديب بحيث تتدمج هذه النصوص أو الأفكار مع النص الأصلي، وتتدغم فيه ليتثكل نصَّا جديدًا واحدًا متكاملًا "(12)

أما القيمة التي يؤديها استلهام التراث في النصوص الثعرية فهي تتسع لتشمل" كلّ ما تقع عليه عين المبدع

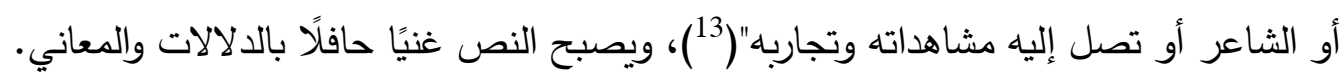

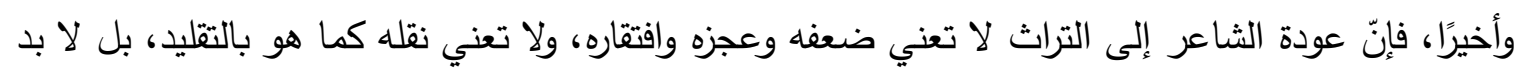
من التفاعل القيّم مع التراث، وهو الإبداع لدى الثاعر المتمكن، و"الثاعر المقتدر وهو يستمد من التراث لا تغيب

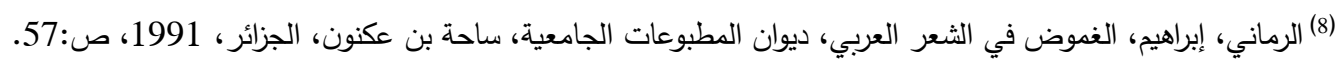

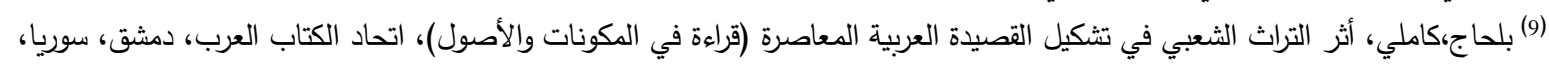

2004، ص:17.

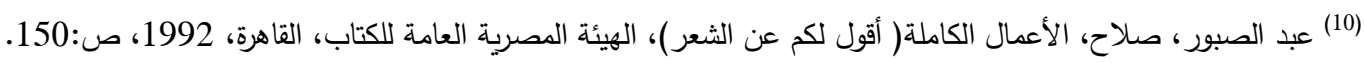

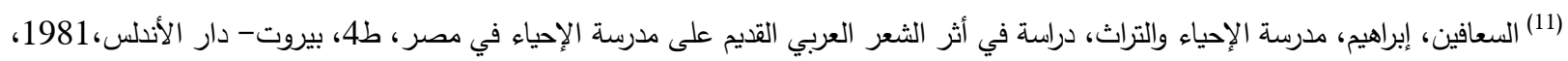


شخصيته أبدًا، بل هو دائم الحضور في إبداعه الثعري، وعميق الإحساس بشخصيته بِعَدِّها العنصر الجديد الفاعل"(14)، فدور الثاعر كبير، فهو" الذي يعيد صوغ هذا التراث وتثكيله، ويتبين ذلك من خلال اختياره نصًا دون غيره، وعلاقته

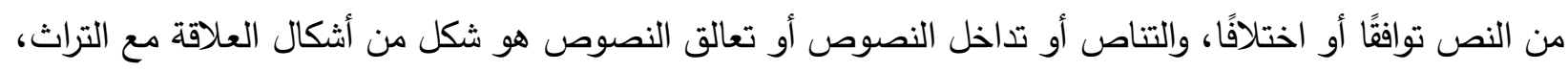

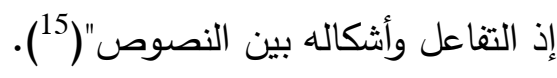

\section{الرافد الايني في شعر صلاح جرار - - أثر القرآن الكريم والحديث في شعره}

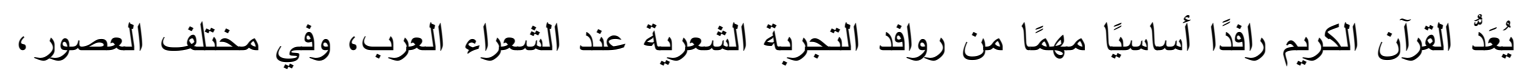
وصلاح جرار واحد من الشعراء الذين عادوا إلى الموروث ووظفوه في شعرهم، وبرز هذا الرافد في الخطاب الثعري

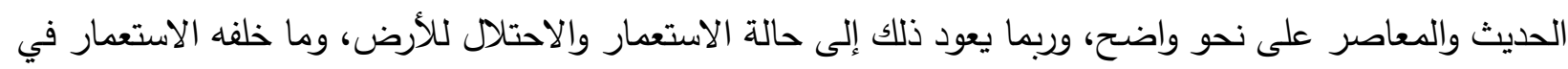
بلاد العرب من ويلات ومصائب، وظلم وقهر طال كلّ مقدس عند العرب، كما تعرض دينهم للتضييق والحرب جراء ممارسات الاستعمار في البلاد العربية، ومحاولة طمس هويتهم، وخاصة في فلسطين مهبط الأنبياء والمرسلين، وقبلة

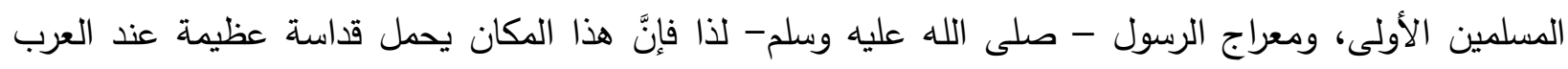
والمسلمين، ف"التطور الذي طرأ على الحياة السياسية والثقافية جعل فرص إفادة الثعراء من القرآن متعددة، وذلك في

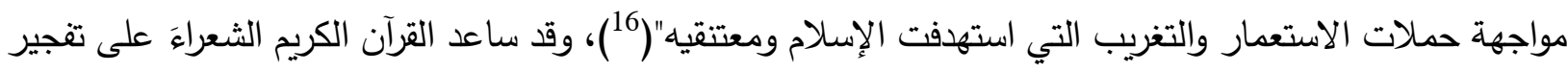
طاقات دلالية إبداعية، وله الأثر الكبير في تقرير بناء رؤيتهم الثعرية، وهم ينهلون منه المعاني والقيم، والثخصيات الدينية وغير الدينية والقصص، فكان التفاعل الكبير بين القرآن الكريم والحديث النبوي الثريف في بناء رؤية فكرية جديدة، و"يقوم على المحاورة للآيات وتثكيل موقف (مع أو ضد)، وهو موقف ربما ظل موضع تردد أو خوف لدى لدى الثعراء قبلًا"( 17)، ولا تقف عند حدود الاقتباس أو التضمين، فكان البناء الجديد للتفاعل مع النص القرآني لا يستند لحدود الاقتباس وتوظيف كلمة أو عبارة، إنّما هو استلهام نص أو فكرة أو قصة وتوظيفها لخدمة الرؤية التي يريد الثاعر توطيدها، ف" شعر الحداثة يختلف في قراءته للنصوص الدينية عن شعراء مدرسة المحافظين (الكلاسيكية) أو

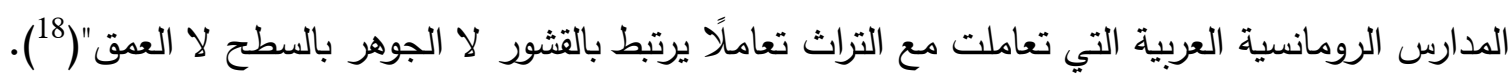

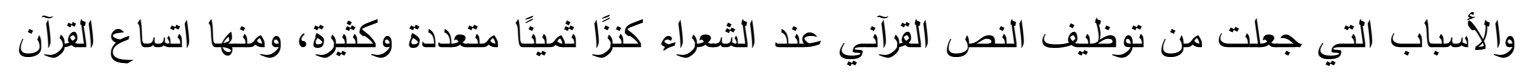
وشموله على المعارف والأسرار، كما أنَّ للقرآن أثرًا في تهذيب الأشعار ، وصقل مواهب الثعراء، وتعليم الأدباء فنون

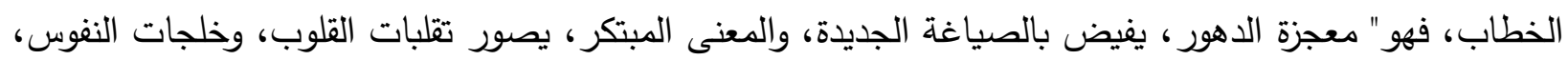

(14) الكوفحي، إبراهيم، توظيف الموروث الديني في شعر حيدر محمود، دراسات العلوم الإنسانية والاجتماعية، العدد الأول، المجلد 28، 2001، ص:

(15) الزواهرة، ظاهر، اللون ودلالاته في الثعر، الثُعر الأردني نموذجًا، ط1، دار الحامد للنشر والتوزيع، عمان، 2008، ص:195.

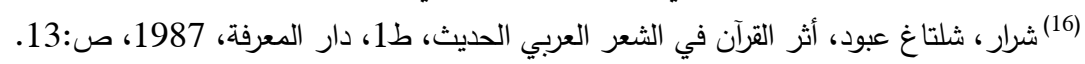

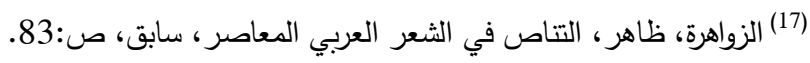

(18) موسى، إبراهيم نمر ، آفاق الرؤية الثعرية، دراسات في الثعر الفلسطيني الثربي المعاصر، ط1، طجامعة بيرزيت: الهيئة العامة للكتاب. وزارة الثقافة،2005، 
وهو النص المقدس الذي أحدث ثورة فنية في معظم التعابير التي ابتدعها العربي شعرًا ونثرًا، ليخلق تشكيلًا فنيًا خاصًا متتاسق المقاطع، تطمئن إليه الأسماع أي الأفئدة في سهولة ويسر "( 19 (19.

ففي قصيدة (طرق مغلقة) يستدعي صلاح جرار النص القرآني في آخر القصيدة؛ إذ يتضح من بداية القصيدة حالة الضعف التي يعيشها العرب، وقد أوصدت الأبواب:

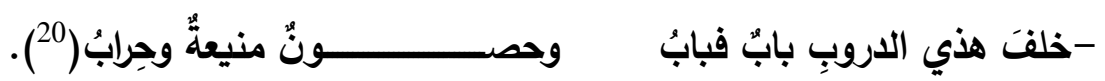

وإذا الأبواب كثيرة، والحصون منيعة، فالحرب وحدها هي الطريق للوصول إلى الأماني والتحرر، والخلاص من الذئاب:

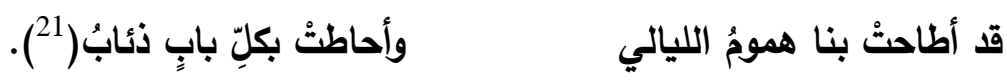

ويأتي الذٔبب بصورته المنفرة القائمة على الموت والغدر والخديعة؛ ليكون بعد الباب هو الحاجز المنيع، وتأتي

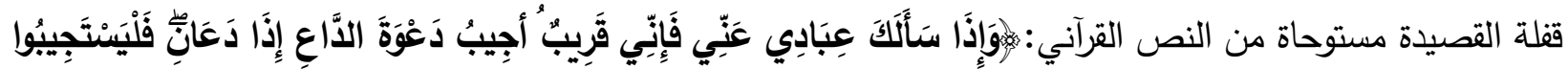

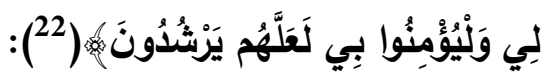

$$
\text { ودعاءٌ - إذا دعا- مُستجابُُ(23). }
$$

لي صديقٌ له مقامُ حميدُ

لكن استلهام النص القرآني يحمل في طياته المفارقة بين استجابة الدعاء من الله، ومن ثم ما يترتب على قوم نيام لم يستجييوا للدعاء، فالدعاء لله (مستجاب)، ولكن من من قوم (غير مستجاب)، فهم لم يستجيبوا لدعاء أمتهم وأوطانهم؛ إذ يقول:

\section{لا تحاولْ صلاحَ قومٍٍ نيامٍ لو يناديهم الملا ما أجابوا (24).}

لقد جاءت الأفعال مسلوبة التأثير، وفي صيغة النهي أحيانًا (لا تحاول، ما أجابوا، لو ناديتهم)، بل لقد جاء بكلمة قوم نكرة لتفضي إلى دلالة الواقع العربي من الضعف والنسيان، فهم مجرد قوم من الأقوام المنسية الضعيفة. ويستحضر جرار النص القرآني في قصيدة (الثهيد) التي تحمل عنوانًا دينيًا يرتبط بالموروث الديني، والثاعر يعدد مناقب الثهيد وتضحياته في سبيل دينه وأمته، وقد نذر نفسه للشهادة وصدق الوعد، يقول جرار :

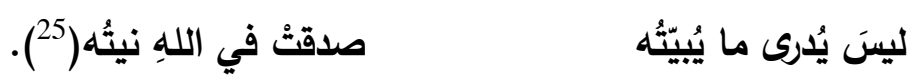

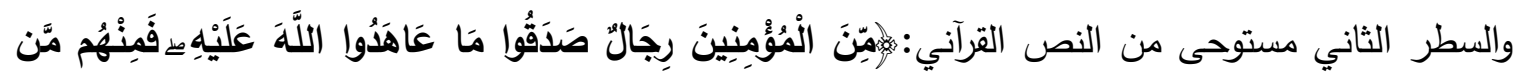

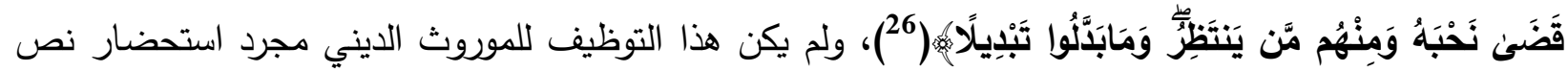

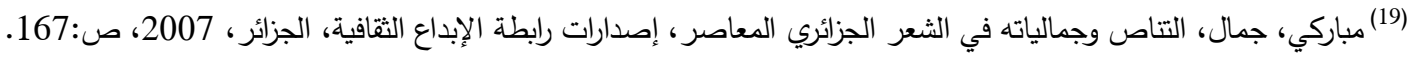

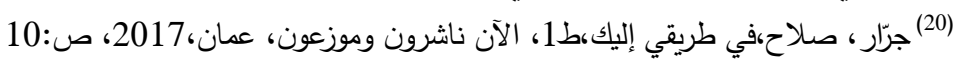

$$
\begin{aligned}
& \text { (21) السابق نفسه، ص:10. } \\
& \text { (22) سورة البقرة آية: } 186 .
\end{aligned}
$$

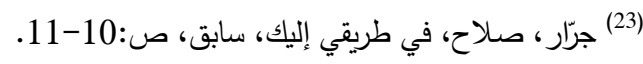

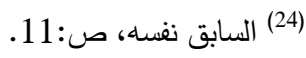

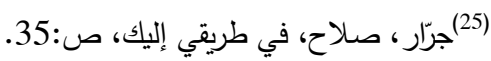

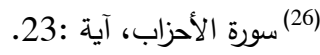


قرآني، بل أراد جرار أن يسقط حال الأمة من خلال هذا الاستحضار، فكانت الضمائر في الأفعال في صيغة المفرد (يدرس، يبيته، صدقت، نيته)، وهذا ما انعكس على حالة الشهيد حين خاض الموت وحيدا:
خفيتٌ عنّا طويته() (27).
خاضَ بحرَ الموتِ منفردًا
ولكن هذا الإقدام وبذل الروح مبرر إذ كان في سبيل الأقصى:
هي للأقصى هديته( (18).

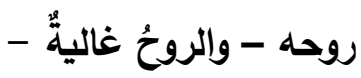

وعندما تقدم الروح للأقصى/الوطن، فانّ الوطن هو من يثيّع الثهيد؛ لأنَّه لا يحتاج شكرًا من فرد، ولا يهمه

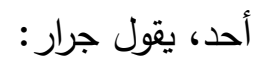

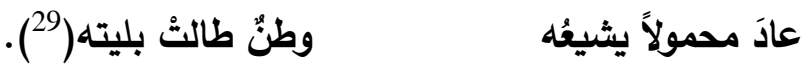

أما في قصيدة (بغاث) فإنَّ استلهام الموروث يبدو جليًا في أكثر أبياتها من خلال المعاني الدينية، والنداء، وكاء والاستغاثة، وكذلك النص القرآني، ويظهر النص حالة الضعف والاستسلام التي وصل إليها العرب، والتخلي عن أرضهم المحتلة، إذ يقول الثاعر : والهن

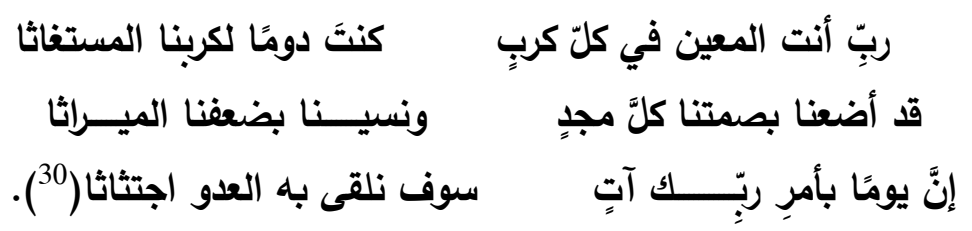

وعند قراءة المقطع الثعري تجد المفردات تكثف عن حالة الضعف(قد أضعنا، نسينا، بضعفنا)، وإن كانت بضمير الجمع الذي يعني القوة افتراضًا إلا أنَّ الأفعال(أضعنا، نسينا) سلبت الضمير أثره الإيجابي ليكون عكس المتوقع والمنتظر، إذ إنَّ الذي ضاع هو المجد، ومع أنَّ قفلة القصيدة توحي بالأمل بل اليقين بالنصر الذي سيأتي مثلما يأتي

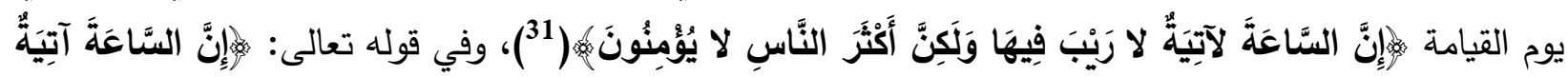

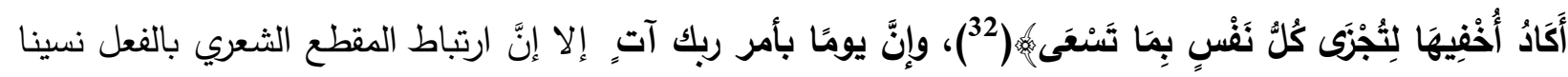
سلب المعنى الإيجابي المرتبط بدحر العدو والنصر . ومثل هذا التوظيف في سياق البحث عن واقع غير الواقع المليء بالهزيمة ورائحة الموت تجده في قصيدة (قرب وبعد) التي تحمل في عنوانها التضاد والتنافر ، وهو إيحاء لحالة الحيرة التي يعيشها الثاعر : تلفّتَ نحو الدارِ والثوقُ يشتدُّ وبحرُ المنايا في المدائن يمتدُ(33).

$$
\begin{aligned}
& \text { (27) جرّار ، صلاح، في طريقي إليك، سابق، ص:35. } \\
& \text { (28) السابق نفسه، ص:36. }
\end{aligned}
$$

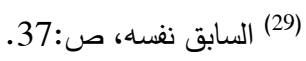

$$
\begin{aligned}
& \text { (30) السابق نفسه، ص:39. } \\
& \text { (31) سورة غافر ، الآية:59. } \\
& \text { (32) سورة طه، الآية:15. } \\
& \text { (33) جرّار ، صلاح، في طريقي إليك، سابق، ص:44. }
\end{aligned}
$$


إنَّ هذه الحالة المواتية التي تسيطر على الثاعر والمدن تسلب الثوق الذي في قلبه، فالمكان الذي هو المرتكز

الضوئي في النص مسلوب، وعندما يكون المكان في خطر فانَّ ساكن المكان يكون مضطربًا خائفًا (تلفّت)، وبحر المنايا مستقر في المكان (المدائن)، ويستلهم الثاعر النص في الحديث النبوي الثريف: عن علي بن أبي طالب عن رسول الله- صلى الله عليه وسلم-: ( أنَّهَ كان إذا قام إلى الصلاة قال: وجهت وجهي للذي فطر السماوات والأرض حنيفًا وما أنا من المشركين، إنَّ صلاتي ونسكي ومحياي ومماتي لله رب العالمين لا شريك له وبذلك أمرت وأنا من

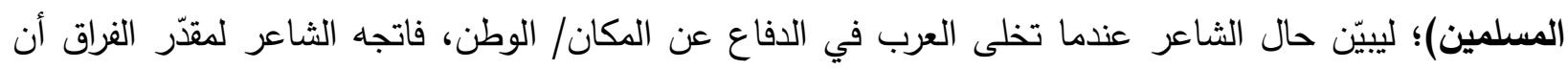
ينزل الرحمة أو بعض رحمته على المكان:

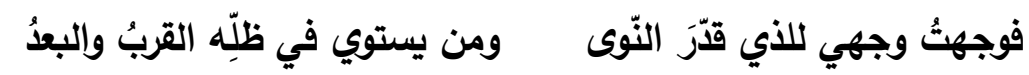
وناديثُ يا رباه لو بعضَ رحمةٍ

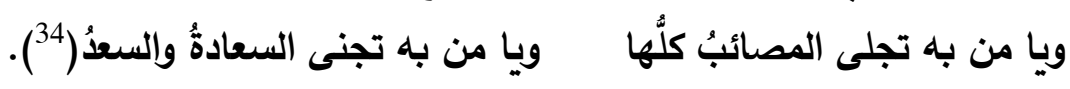

كما يستلهم صلاح جرار النص القرآني ليبيّن تغير الحال الذي أصاب الأمة، والتبديل الذي آلت إليه، حين ضاع المجد وأصبح هباء، ففي قصيدة (صولات) يقول: ئلان

$$
\begin{aligned}
& \text { أيا غزةَ المجدِ لو كان لي سبيلٌ لخضتُ إليك البحارا }
\end{aligned}
$$

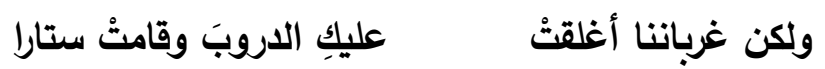

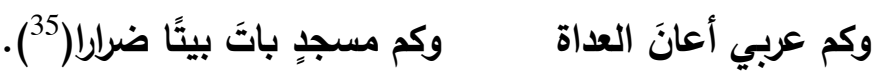

فلموروث حضور بارز في استحضار صورة الغراب، وهو الطائر الذي ارتبط عند العرب بالثؤم، وجاء توظيفه ليحمل دلالة رمزية لكلّ من وقف ضد أهل غزة، وكلّ من ساهم في الانقسام الداخلي والخارجي للأمة، وهؤلاء هم من أعان الأعداء على العرب؛ لذا كان التوظيف للنص القرآني معبرًا عن حالة الانقسام هذه باستحضار مسجد

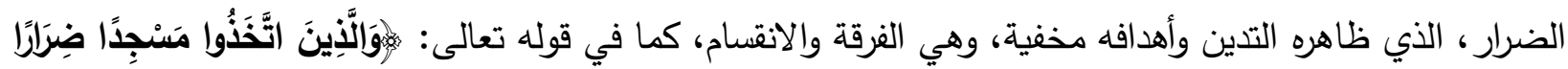

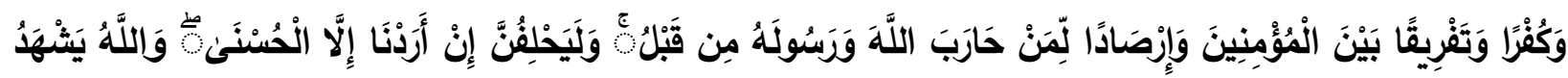

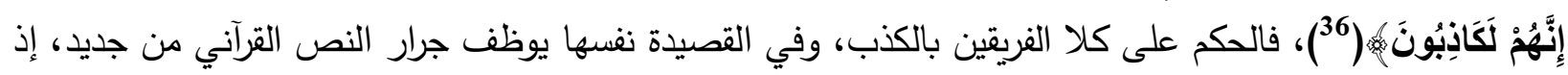
يقول:

$$
\begin{aligned}
& \text { لقد وهنَ العربُ يومَ الصدامٍ وكان سكوتُ الأعاريب عارا }
\end{aligned}
$$

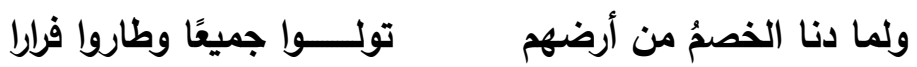

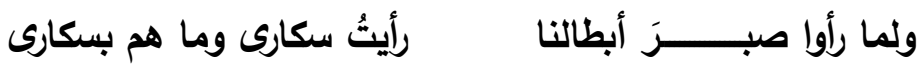

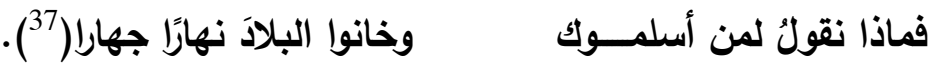

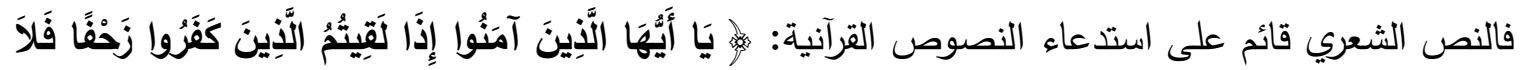

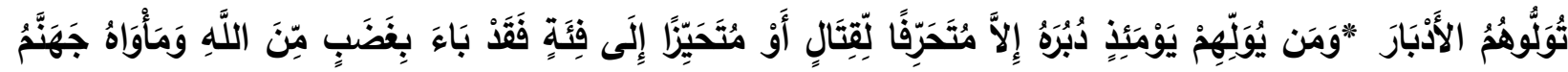

$$
\begin{aligned}
& \text { (34) السابق نفسه، ص:44. }
\end{aligned}
$$

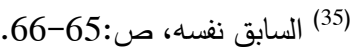

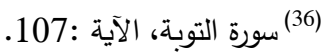

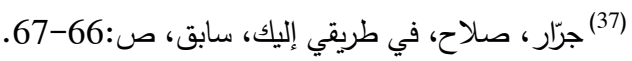




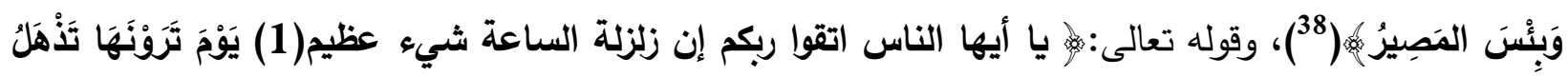

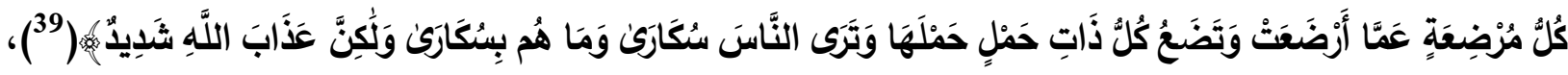

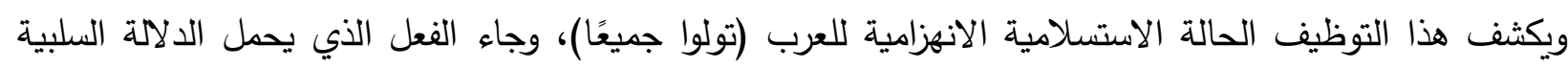

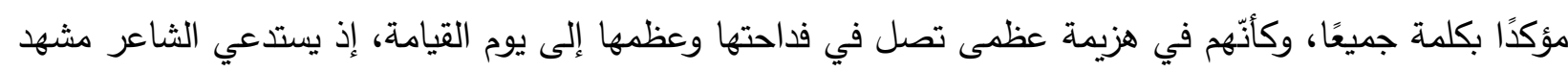

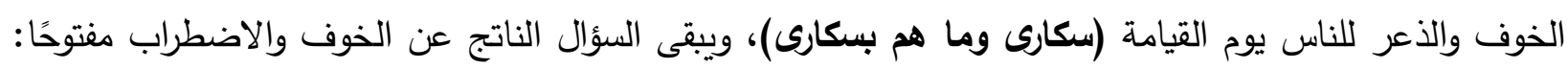
ماذا نقول لمن أسلموا الأقصى، وخانوا البلاد؟ لإن

وعندما يستلهم جرار النص القرآني، وفي سياق الموضوع المؤرق لأبناء الأمة، وهو احتلال الأرض وضياعها،

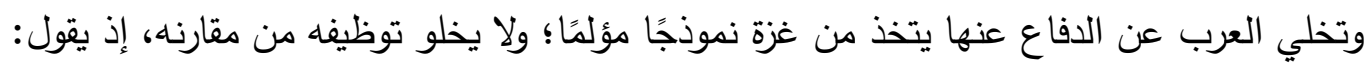

\section{إنّ دمعي وقد ذكرثُ بلادي عادَ من لهفتي لها لها أن يسيلا

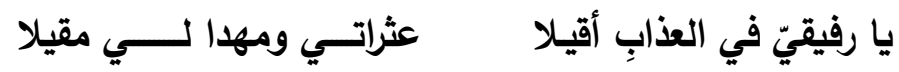

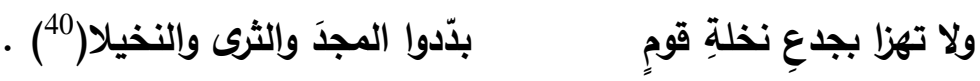

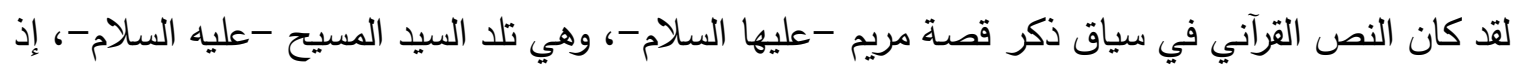

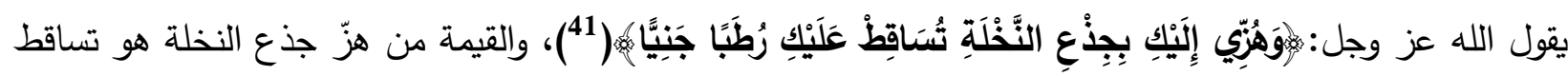

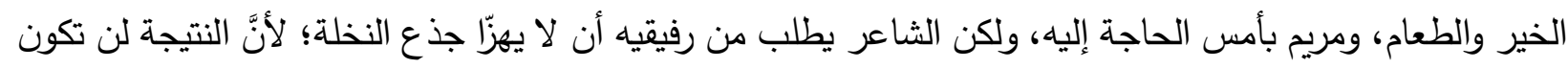

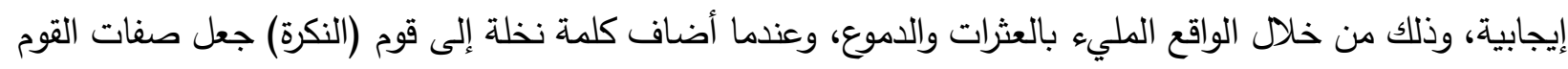

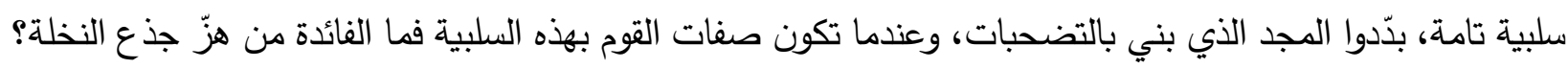

ويستلهم جرار في قصيدة (شهاب ناطق) النص القرآني ليبيّن سبيل النصر موظفًا المعاني الدينية، فيقول:

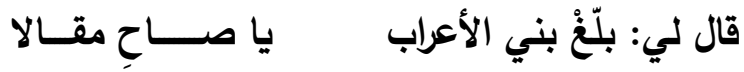

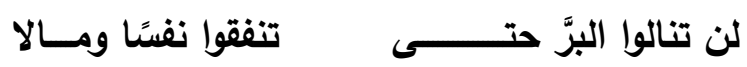

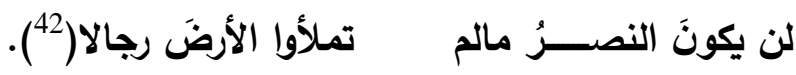

والحقيقة الماثلة من خلال الموروث الديني المستدعى في النص الثعري لا يكون إلا بإعداد العدة من المال

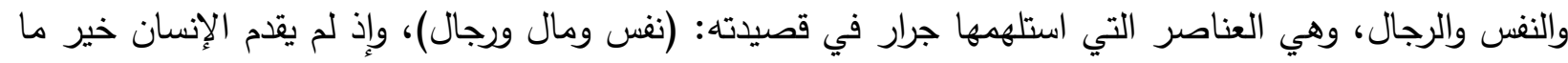

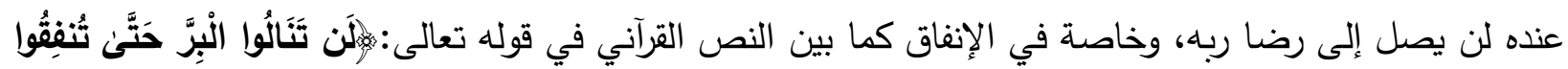

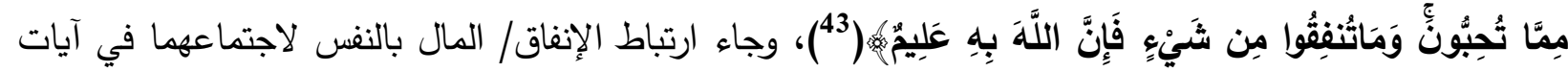

$$
\begin{aligned}
& \text { (38) سورة الأنفال، الأية:2. }
\end{aligned}
$$

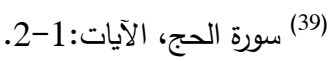

$$
\begin{aligned}
& \text { (40) جرّار، صلاح، في طريقي إليك، سابق، ص:139. } \\
& \text { (41) سورة مريم، الآية:25. }
\end{aligned}
$$

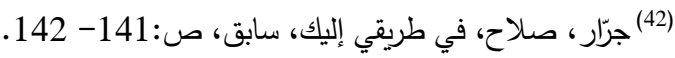

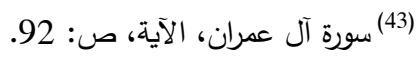




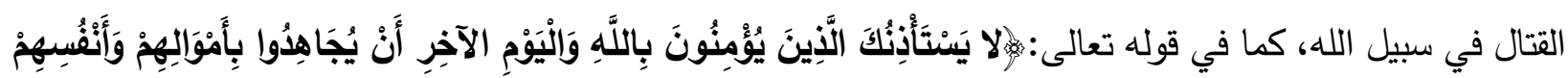

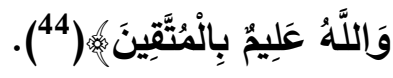
كما يوظف جرار الموروث الديني في قصيدة (قمر الليل) التي يرمز بها إلى غزة:
كيف نرضى عن النزالِ بليلا
نحن قومُ أعزنا اللهُ دهرا

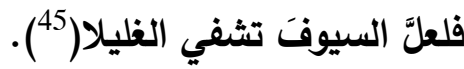
حكّم السيفَ في رقابِ الأعادي

وهذا مستمد من قول عمر بن الخطاب- رضي الله عنه-: (قدم عمر بن الخطاب الجابية على طريق إيلياء على جمل أورق، تلوح صلعته للشمس، ليس عليه قلنسوة ولا عمامة، تصطفق رجلاه بين شعبتي الرحل بلا ركاب، وطاؤه كساء انبجاني ذو صوف هو وطاؤه إذا ركب، وفراشه إذا نزل، حقيته نمرة أو شملة محثوة ليفاً، هي حقيبته إذا ركب ووسادته إذا نزل وعليه قميص من كرابيس قد رسم وتخرق جنبه. فقال: ادعوا لي رأس القوم، فدعوا لله

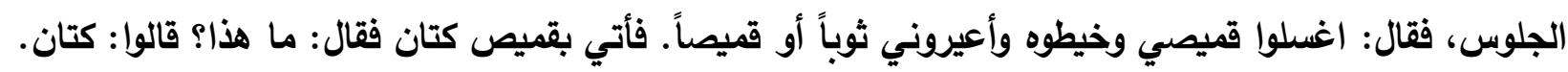

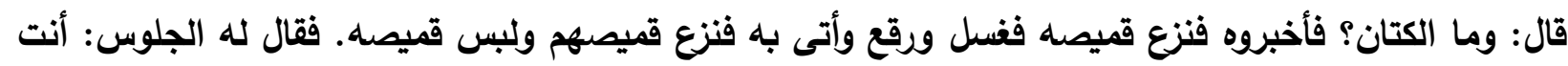
ملك العرب وهذه بلاد لا تصلح بها الإبل، فلو لبست شيئاً غير هذا وركبت برذوناً لكان ذلك أعظم في أعين الروم.

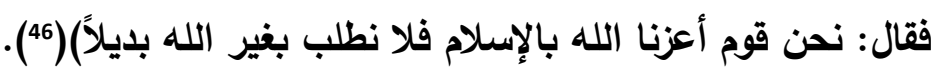
فالعزة مستمدة من التمسك بالدين والإسلام، ولا عزّ ولا نصر بسواه، وكذلك النصر لا يكون بغير القتال، ويريد

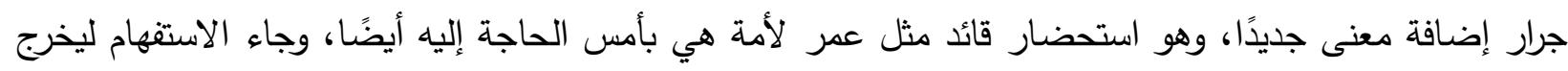
إلى معنى الإنكار وينسجم المعنى البلاغي مع المعنى الدلالي، وهو النفي.

\section{الرافد الأدبي والتاريخي في شعر صلاح جرار}

$$
\text { أ- استلهام الثخصيات الدينية والتاريخية في شعره }
$$

لا يستحضر جرار الشخصيات التراثية في خطابه الشعري في ديوانه (في طريقي إليك) إلا قليلًا، مما يشكل

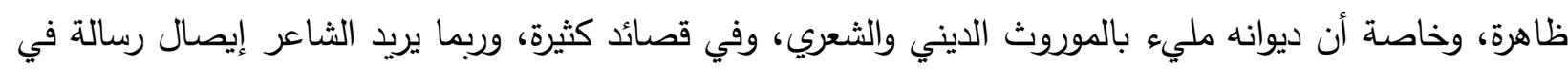

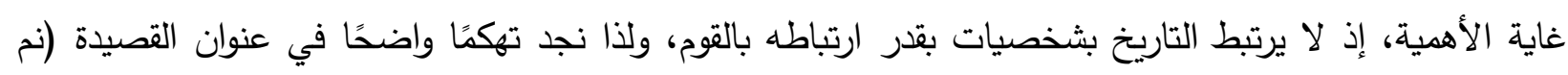

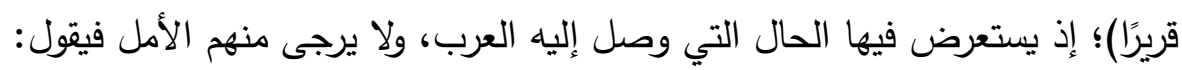

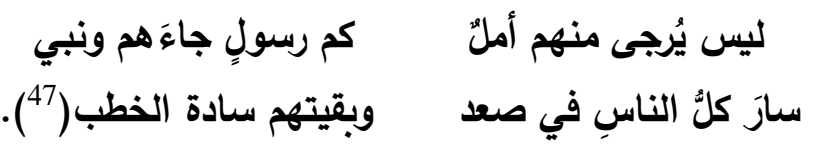

ويستحضر جرار هنا الصفة لا الاسم (رسول ونبي)، وبلا عدد، والنتيجة التي نلحظها مؤلمة، إذ ليس لقومه فعل ولا عمل سوى الكلام، فهم سادة الخطب، والناس سادة النهوض، وهذه مفارقة بيّنها عنوان القصيدة (نم قريرًا)، 
والتهكم من أمة توصف بكثرة الكلام، ولا تدرك المعادلة الحقيقية للنصر ، وهي الجهاد والتضحية، فالنصر لا يأتي من السماء دون جهاد وعمل.

كما يوظف الثخصية الدينية والتاريخية في قصيدة (لن يمر) يقول:

\begin{tabular}{|c|c|}
\hline ثوبَ فنــــر تجرُ & غزة العزة أضحتُ \\
\hline آخر الصبر نصرُ & غزة المجد صبرًا \\
\hline ثارَ رمـــلُ وبحرُ & إن أتتها ريــــح \\
\hline هبَّ زيدٌ وعمرو & أو أتاها نــــاء" \\
\hline قادها اليوحَ نسرُ & بطثة في عـدو \\
\hline
\end{tabular}

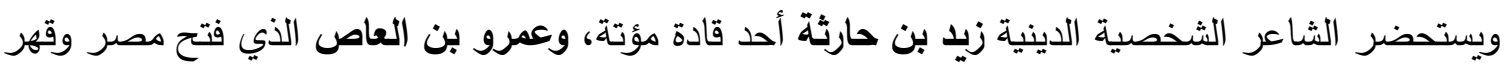

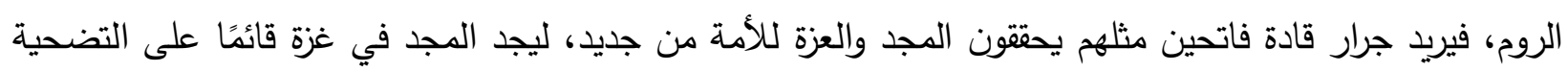
والفداء.

ب- أثر الموروث الثعري القديم في شعره

يبدو أنَّ الموروث الثعري ظاهرٌ جليّ في الخطاب الثعري عند صلاح جرار، ولم يقف عند حدود التأثر بالأساليب، واقتفاء طريقة القدماء في الوقوف على الطلل، ومخاطبة الرفيقين كما في قوله:

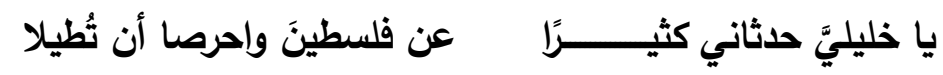

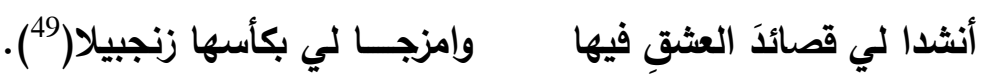

وإذا كان الثاعر الجاهلي يريد الرفيق لعونه وتسليته في رحلته الثاقة، فإنَّ صلاح جرار يريد الرفيق معينًا

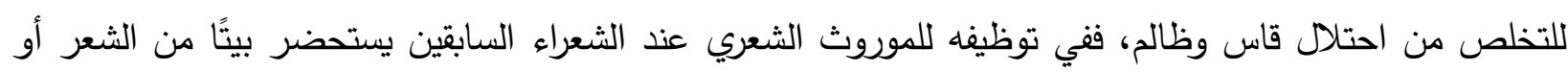
شطر بيت.

وعندما يستحضر جرار نصًا للشعراء القدامى فإنَّه يستحضر قصيدة كاملة بكل ما تتضمن، ويختزل فيها العديد

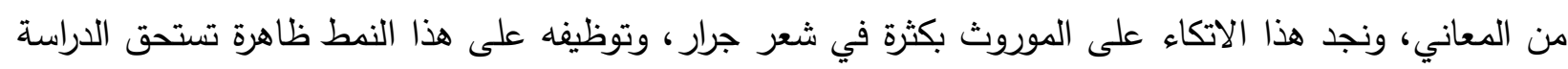

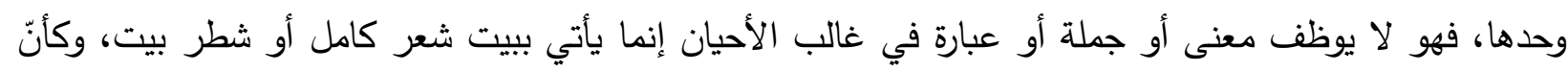
جرارًا يوصل لنا رسالة تحمل القداسة للنص الثعري القديم، يقول جرار في قصيدة" قمر الليل": - حكّم السيفَ في رقابِ الأعادي فلعلّ السيوفَ تثفي الغليلا(50).

$$
\begin{aligned}
& \text { (48) جرّار، صلاح، في طريقي إليك، سابق، ص:60. }
\end{aligned}
$$

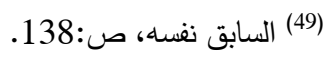

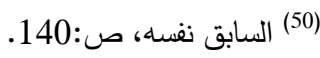


إذْ يستحضر جرار قصيدة عنترة بن شداد:

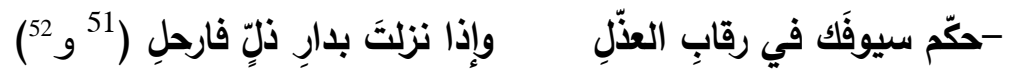

وإذا كان عنترة بن شداد يستحضر هذا المعنى الفروسي في التعامل مع العذّال، الذين لا يريدون القتال، لأجل

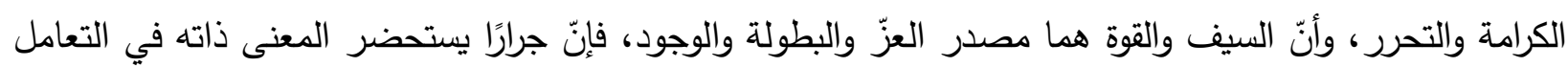

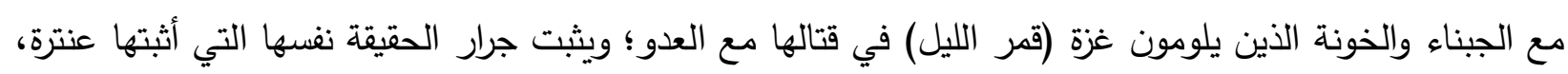
وهي أنّ السيف هو الذي يأتي بالحقوق ويحمي الذمار ، وهذا التوظيف في السياق ذاته يبذو في قصيدة (حداء الأصيل)

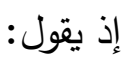

إذا فكرّتَ في أمرٍ عظيمٍ فما نيل المنى بالمستحيل(53).

$$
\text { وجرار هنا يستلهم الموروث الثعري في قول أحمد شوقي: }
$$

ولكن تُؤخذَ الدنيا غلابا

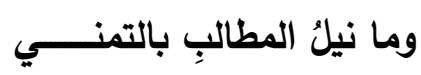

وما استعصى على قومٍ منالِّ إذا الإقدامُ كان لهمْ رِكابا(54).

فقصيدة جرار تعكس حال الحزن، والهمّ العظيم، والقلب المريض، وهو انعكاس لحال الأمة، فليست الهموم خاصة بقدر ما هي هموم عموم الأمة:

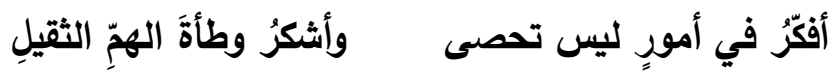

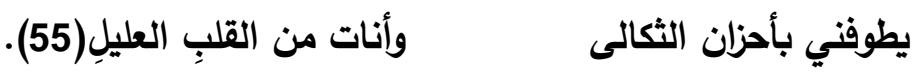

لكنّ حالة اليأس هذا تستوجب النهوض كما تستوجب بناء أمل عظيم، وهذا الهمة تقود إلى التحدي، ولذلك يوظف جرار قول شوقي الذي يحمل هذا المعنى على سبيل الحكمة التي تعيش ولا تموت، وتسمو ولها الخلود، فإذا لتأ

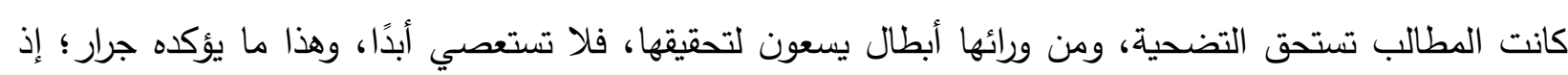

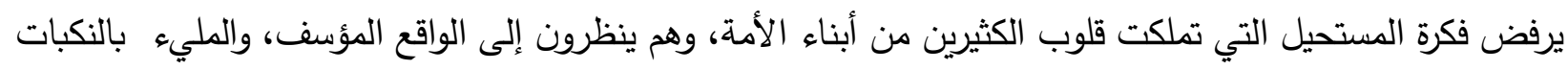
والهزائم.

ويستلهم جرار أيضا قول أبي القاسم الثابي المشهور في قصيدته المُحفّزة على النهوض، وبث روح العزيمة والنصر والقوة في نفوس شباب الأمة، إذ يقول في قصيدة (شآبيب السماء):

(51) ابن شداد، عنترة، ديوان عنترة.608م، تحقيق ودراسة محمد سعيد مولوي،المكتبة الإسلامية، 1970، ص:134.

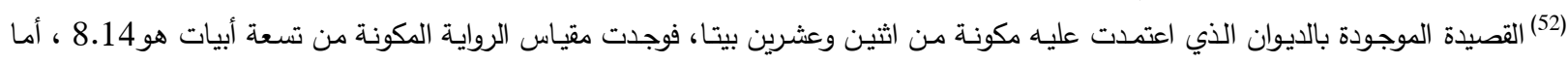

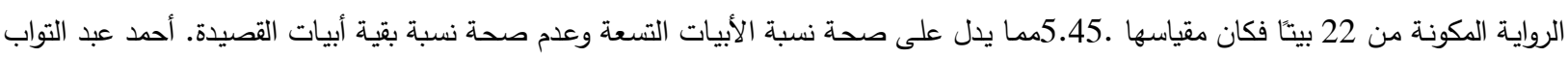

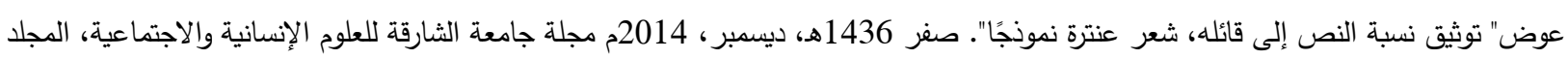
11 العدد 2 ص:147.

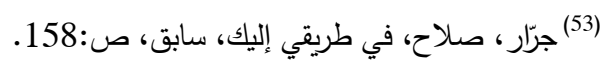

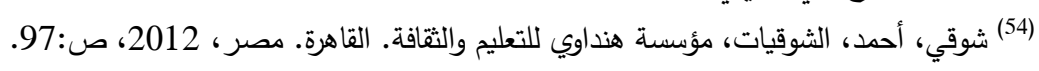

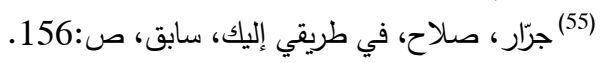


ولكن إذا ماتمادى الظلامُ " فلا بُدَ لليل أن ينجلي"(56).

ويريد جرار أن يقرر حقيقة ترتبط بالأمل والعزيمة، وأن النصر آتٍ لا محالة، وإذا كان الليل مظلمًا وطويلًا

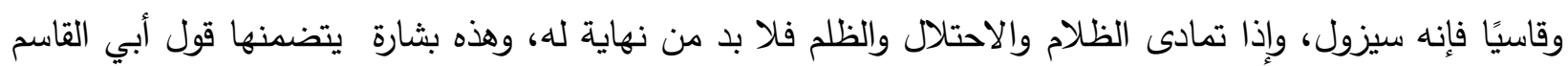
الثابي:

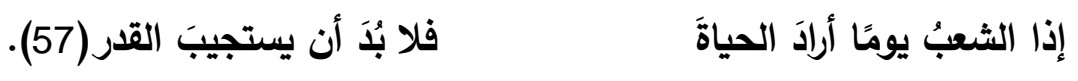

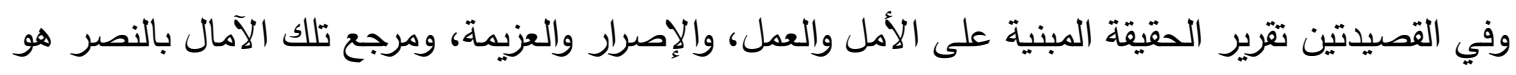

الثعب الذي يمتلك القوة في التحرر، وردع الظلم والظالم؛ ولذا جاء الدعاء في أول القصيدة ينبئ عن الأمل:

لك المجُ يا مالكَّ الأمنياتِ أعدْ لي بعضَ الذي كان لي(58)

$$
\text { ويستحضر جرار قول أبي نواس: }
$$

دوُ عنك لومي فإنَّ اللومَ إغراءُ وداوني بالتي كانت هي الداءُ 59، إذ فيقول في قصيدته (هذه الورود بلون خدك):

$$
\begin{aligned}
& \text { هذه الورودُ بلون خدك فامنْ عليَّ ببعض وردك } \\
& \text { وانهضْ إلــــيَّ بوردة واحملْ إلــي جميلَ وعدلك } \\
& \text { لدُ عنك لومي في الهوى فالنفسُ مولعةٌّ بوردك(60). }
\end{aligned}
$$

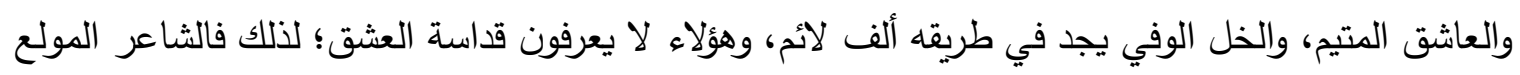

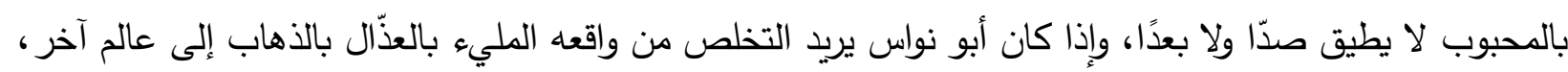

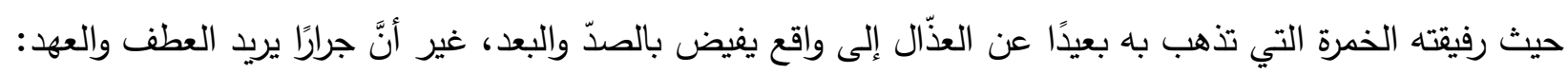

$$
\begin{aligned}
& \text { فاعطفْ عليَّ بما ترىى واحفظْ عليَّ وثيقَ عهدك } \\
& \text { وارأفت بقلٍٍ مرهفٍ ما زالَّ يطلبُ حسنَ ردك(1). }
\end{aligned}
$$


وكذلك تجد استحضاره لنص آخر ، يريد من خلاله أن يبين صدقه ووفاء عهده، عندما يعقد مقارنه بينه وبين أبناء قومه، وهم الذين ينصبون له المكائد، ففي قصيدة "غاية الحرّ" يقول جرار:

غُصصًا وقعُها عليَّ ثقيلُ

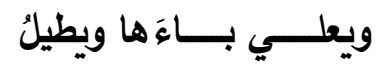

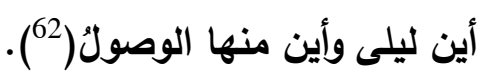

إنَّ بيني وبين أبناءِ دهري

كلُّهم ينصبُ المكائدَ ضدي لئن

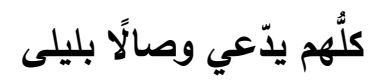

$$
\text { وهذا مستلهم من قول الثاعر أبي العتاهية: }
$$

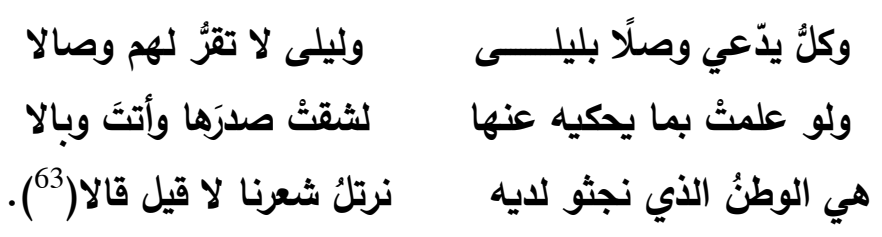

ويبيّن جرار هنا فئة من الذين يدّعون عشق البلاد والتضحية لأجلها، لكنهم عند الحاجة لا يكونون، فالكلام سهل والادّعاء أسهل، ولكن العمل والأثر يعكسان صورة المحب المخلص، فالكل يدّعي حبَّ ليلى/ الوطن، والكلمة المحورية هنا هي الادّعاء التي توحي بالكذب والخداع، ولكن أين هو هذا الحبّ؟ وما ثماره؟ وماذا قدموا؟ لذا كانت القصيدة قائمة على المقارنة التي عرّت الغادرين:

\section{والبلايا على ذوي المجدِ تترى كالحاتٍٍ وكلّ حين تصولُ

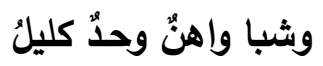

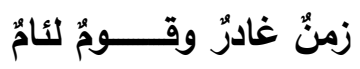

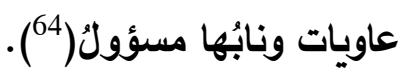 \\ وذئَابٌ تحومُ حولَ ذماري}

والمفردات المنسجمة مع حال الضعف والألم كثيرة (البلايا، وكالحات، وزمن غادر، وقوم لئام، وشبا واهن، وذئاب)، وتكثف عن معنى الاذّعاء الذي هو أشبه بالمؤامرة.

ت - العنوان والموروث في خطابه الثعري

إنّ العنوان في القصيدة الحديثة ركيزة مهمة في توضيح أبعاد القصيدة ومحتواها، فهو حالة الصدام الأولى مع الحع المتلقي؛ ولهذا لا بد من الاهتمام به واختياره بدقة، فالعنوان" ليس كلمة عابرة توضع اعتباطًا، بل يتم اختيارها أو اللجوء

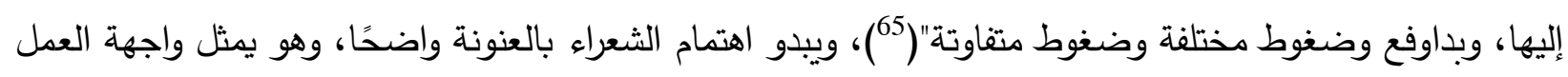
الأدبي وهو مفتاح الدخول إلى النص، ف" العنوان يوجه في كثير من الأحيان إلى مضمون العمل، وثمة وظائف للعنوان

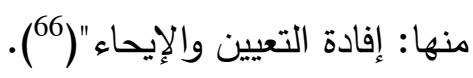

والناظر إلى قصائد ديوان صلاح جرار (في طريقي إليك) يجد العديد من القصائد المعنونة والمتعلقة بالموروث، وخاصة الموروث الديني مثل: (ضراعة، ص:7، وصلاة، ص:9، وابتهالات، ص:33، والثهيد، ص:35:35، يا نار

$$
\begin{aligned}
& \text { (63) - (62) السابق نفسه، ص:125. } \\
& \text { (63) مستلهم من قول الثاعر أبي العتاهية: (وينسب لمجنون بني عامر ). }
\end{aligned}
$$

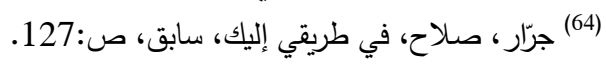

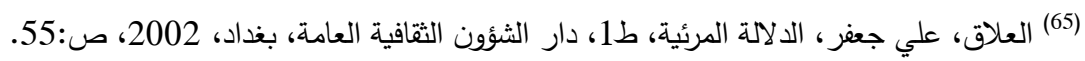

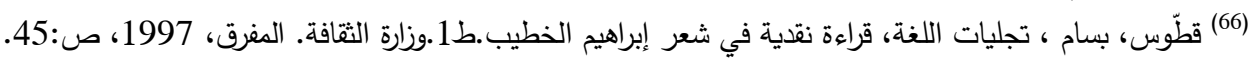


كوني، ص:50، وطاعة وعصيانًا، ص:90، وأغلال، ص:33) وهذه القصائد تبدو من عنوانها أثرًا دينيًا، وهو ما أراده الثاعر عندما تعاني الأمة من الظلم والاحتلال والقهر وسلب الوطن، فهي بحاجة إلى الضراعة والصلاة، والابتهالات والثهادة، بل تبدو في أوضح صور الحاجة للخلاص من الواقع. ففي قصيدة الضراعة يخاطب الثاعر المحتل فيقول:

يا ديارًا رامها المـــلأ أنتَ للتاريخ مبتدأ

ما سوى عينيك لي أملّ وسوى كفيك متكأ(67).

ويبدو الواقع ظاهرًا جليًا في النص الثعري حينما يعكس محتوى النص على عنوانه، إذا القوم قد ضاعوا

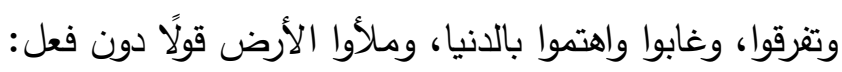

إنَّ قومي قد أطيخ بهم هل أتاك عنهم النبأ؟ ملأوا الانيا مفاخرة وبغير القولِ ما ملأوا (68).

وأمام هذه الحال المؤلمة لا يملك الثاعر سوى الضراعة والدعاء، فكانت مفردات النص تحت سيطرة العنوان الذي بسط أثره بكلِّ وضوح، ويحمل قوله التهكم والسخرية من قوم ملأوا الدنيا، ولكنّهم لم يملأوها مجدًا ونصرًا، إنّما ملأوها مفاخرة وقولًا، وهذا عكس المطلوب وضوح، والمتوقع أمام حالة الضعف والهزيمة. ويعنون جرار قصيدة أخرى بـ(صلاة) وهي قصيدة أخرى يبين من خلالها أنّ الأمة لم تزل حية رغم كلّ

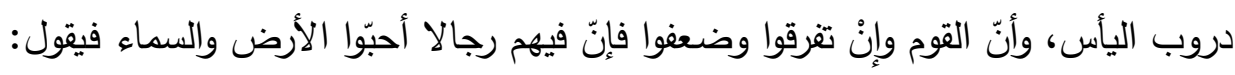
قناديل في جنح الظلام أضاءها

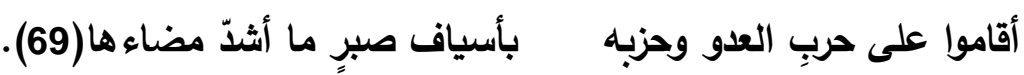

فهم يحاربون ويقاتلون العدو؛ لذا كان العنوان منسجمًا مع المعنى الذي يريده الثاعر في أنّ الرجال هؤلاء موجودون أقوياء، وصلاتهم ليست للدعاء هذه المرة، بل هي للنصر ، يقول جرار : أقاموا صلاةَ النصرِ فوقَ ترابها وكم ذا تباروا يبتفون رضاءها(70).

وفي قصيدة (الثهيد) جاء العنوان مختزلًا لكلّ قصص البطولة والتضحية والنصر ، وعزة الأمة ونهضتها؛ "إذ يُعدُّ العنوان سمة العمل الفني أو الأدبي من حيث هو يضم النص في حالة اختزال وكمون كبيرين، ويختزل فيه بيئته

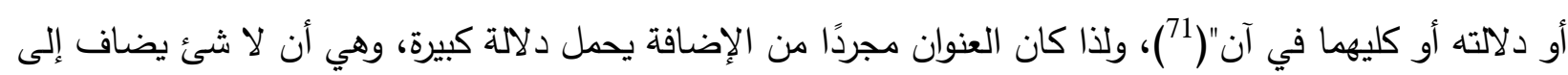
الشهيد، أي لا صفات تحصر به، فهو الذي يخوض بحر الموت كما قال جرار :

$$
\begin{aligned}
& \text { (67) جرّار، صلاح، في طريقي إليك، سابق، ص:767. }
\end{aligned}
$$

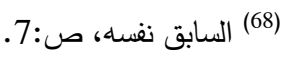

$$
\begin{aligned}
& \text { (69) جرّار ، صلاح، في طريقي صن إليك، ص:98) } \\
& \text { (70) السابق نفسه، ص:9 (70) } \\
& \text { (71) قطّوس، بسام، سيمياء العنوان. ط1، وزارة الثقافة. عمان، 2001، ص:39. }
\end{aligned}
$$




\section{يركبُ الأخطار متئدا ومراميها مطيته(72).}

وهو الذي يدافع عن الأقصى: (ورضا الأقصى قضيته).

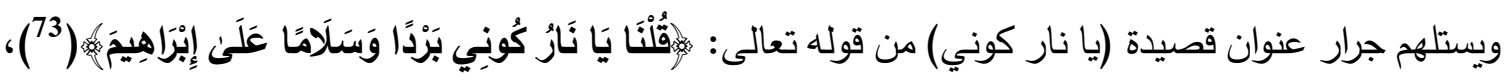
وهذا العنوان يرتكز على النص الديني، والناظر لكثير من قصائد الثعراء المعاصرين يجد" أنَّ اهتمامًا واضحًا لدى جـى الثعراء في أن تكون عنوانات قصائدهم ذات صلة دينية، ومنها ما كان حرفيًا لجملة دينية مأخوذة من نص ديني في حين كثرت العنوانات التي تحمل المعاني الدينية في كثير من قصائدهم؛ وذلك لإكساب هذه النصوص بعدًا جماليًا

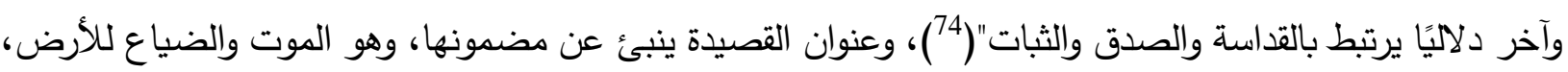
وبعد الأحباب، يقول جرار :

هي ذي العين تقطعُ الليلَ سهدا وديارُ الأحبابٍ تزدادُ بعدا(75).

وكأنّ العنوان يحمل الدعاء لهذه الأمة عندما تكالب عليها الأعداء، وأحاطت بها البلايا ونار العدا، وكأنّ جرارًا يريد القول: يا نار كوني بردًا على هذه الأمة، ويستلهم أيضًا من خلال النص القرآني صبر إبراهيم على ما فعل

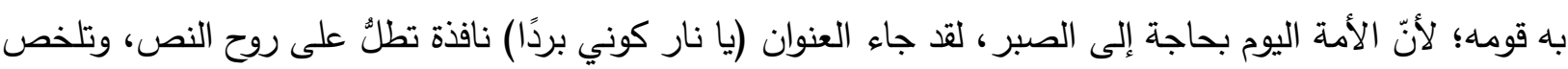
قصّة دينية بأكملها، وما تتضمن هذه القصة من دروس وعبر، ولذا يتكىع الثاعر على قصة إبراهيم ويختار بعناية البؤرة الفارقة في النص (كوني) بعد النداء (يا نار)، وكأنّ الثاعر لم يجد ما يعين لإنقاذ الأمة، ويكتفي بالدعاء إلى ولى السماء للخروج من الواقع، إذ الخالق وحده من يجيب، فيقول:

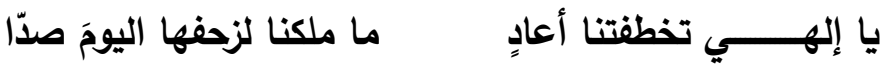

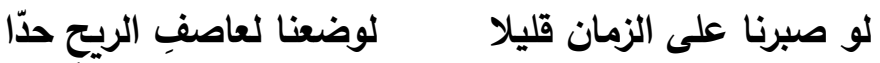

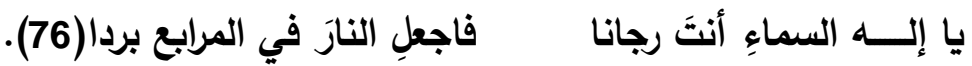

ويستحضر جرار عنوانات أخرى من الموروث الثعري كما في قصيدة (بانت سعاد) التي تحمل عنوانًا مختزلا

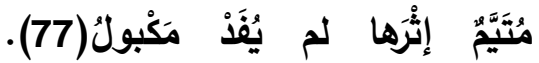

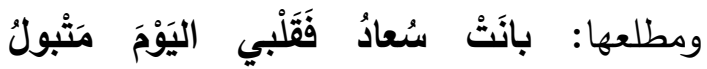
وجرار في استلهامه لقصيدة بانت سعاد يبني نصًا يقوم على القوة والصمود، وعلى سبيل المفارقة المحزنة، فإذا كانت سعاد قد بانتُ وابتعدتُ، فالبطل المقاوم والمحارب للعدو ما بان ولا ابتعد، بل هو صامد مقدام كما يقول:

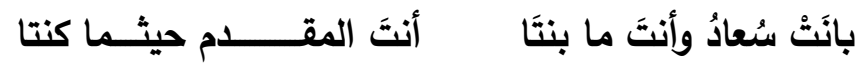

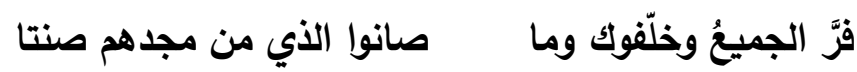

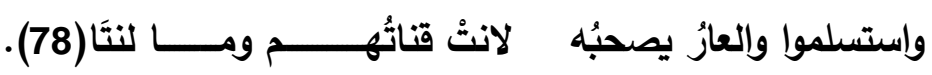

$$
\begin{aligned}
& \text { (72) جرّار ، صلاح، في طريقي إليك، سابق، ص:35. } \\
& \text { (73) (73) سورة إبراهيم، آية:69. } \\
& \text { (74) الزواهرة، ظاهر، التتاص في الثعر العربي المعاصر، ، سابق، ص:175. }
\end{aligned}
$$

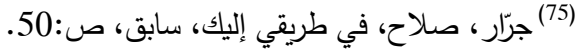

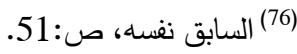

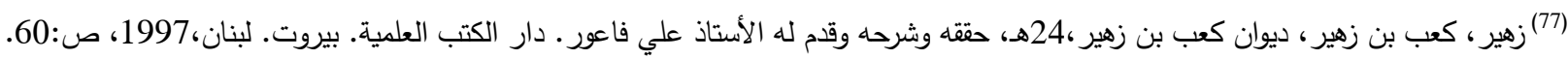

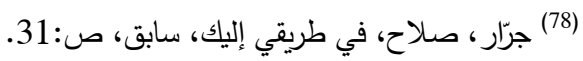


وإذا تخلى بعض الناس عن المقاومة والرجولة، فإنّ البطل الذي يحارب العدو ما تخلى عن سلاحه كما يقول جرار:

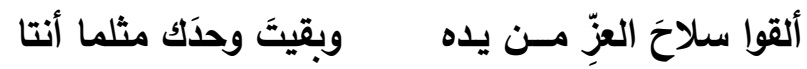

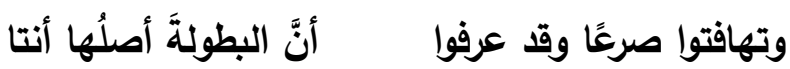 \\ باعوا ضمائرهم وقد غدروا أوطانهم علنًا وما خنتان(79).}

وفي قصيدة أخرى يحمل العنوان عند جرار قضية نقدية قديمة وهي الوقوف على الطلل، فقد جاء عنوان القصيدة (وققة على الأطلال) منسجمًا مع النص الذي يتحدث عنه الثاعر ، فهو نص عن الوطن وأهله، وكيف تثرقوا

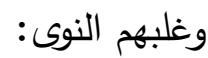

\section{هي النفسُ أقسى ما ألاقي: عذابها ويفزعُ قلبي جرحَها ومصابها}

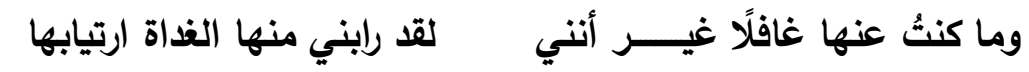

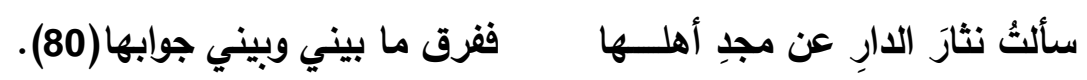

ومثلما وقف الثاعر الجاهلي على الأطلال يستذكر أهل الديار/ ديار المحبوبة وترحالهم ويقتفي آثارهم

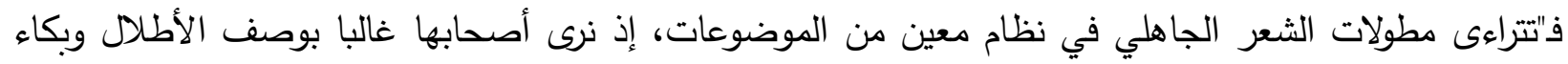

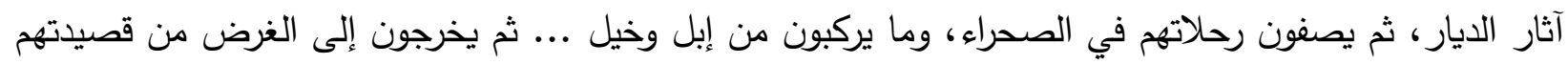

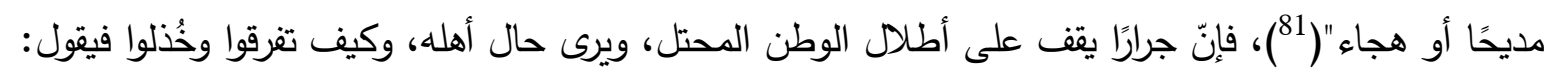
وغابتُ مراسيلُ المحبةٍ بينتا وقد طال في عرضِِ البلاد غيابها(82).

ث- - الخاتمة والموروث في خطابه الثعري

إنّ الخاتمة هي آخر ما يستقر في ذهن المتلقي، وهي ما يبقى عالقًا في الذهن، فلا يقل المقطع في الخطاب التهاب

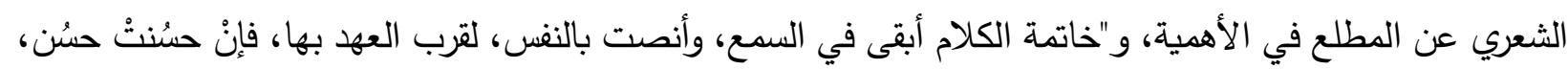

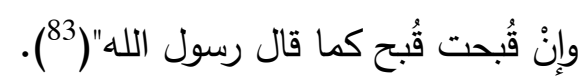
وكثيرة هي القصائد التي ترك صلاح جرار قفلتها بيتًا من الشعر أو شطر بيت من الموروث الثعري، وكأنّه يترك المتلقي بعد قصيدته أمام قصيدة من جديد، لا أمام سطر أو جملة شعرية. ومن ذلك قصيدة (حلم مبدد) التي تتضمن حالة الفرقة والتشرد العربي، وحالة الجهل، وكيف تملك الضعف والحزن أمة كانت أقوى الأمم، يقول جرار : مبد التي

$$
\begin{aligned}
& \text { (79) جرّار، صلاح، في طريقي إليك، ص:31- } 32 .
\end{aligned}
$$

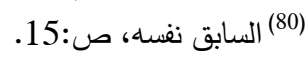

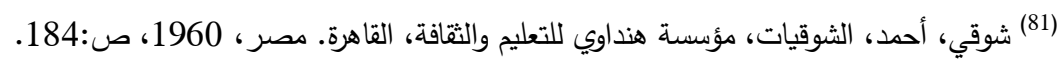

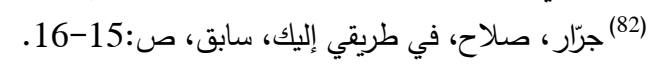

(83) القيرواني، ابن رشيق، العمدة في محاسن الثعر ونقده،456هـ، تحقيق: محمد مجيي الدين عبد الحميد، القاهرة، 1955،ج1،ص:214. 


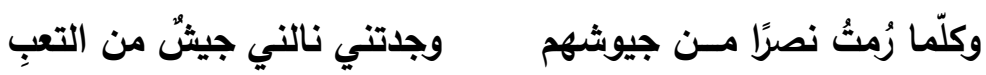

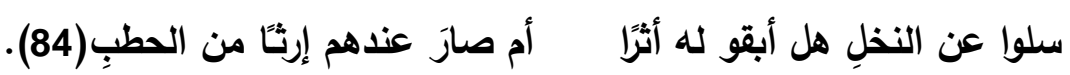

والثاعر بعد هذا الششهد الخطابي المليء بالانهام والتعب في وصف القوم الذين تخلوا عن النصر، واكتفوا

فقط بالخطب والكلام، يترك قفلة القصيدة شطر بيت لأبي تمام ، فيقول:

قد كذبوا حينما قالوا وما فعلوا السيفُ أصدقُ إنباءً من الكتب"(85).

والثطر الثاني مستمد من قصيدة أبي تمام المشهورة:

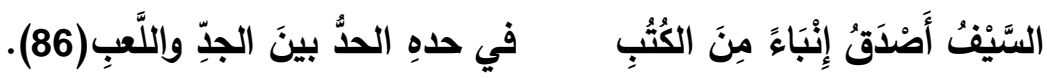

وكأنّ الثاعر يقارن بين حالين وزمنين، حال نصر وقوة كان السيف فيها هو العنوان، والعلم قوة، والحق يسترد

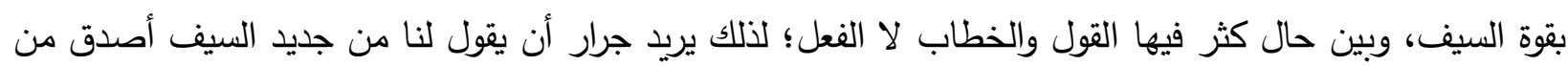

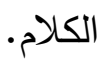

وفي قصيدة أخرى يأتي التوظيف ذاته، ففي قصيدة (سيف الثعر) تتضمن القصيدة أهمية الثعر ، والثبات على المبادئ والقيم، ويصف الرجال الرجال الذين يقفون في صدق القول، ولا يتلونون مع صروف الدهر، فقد كان الظلم قد صنع ما صنع في أمة العرب كما يقول جرار :

ويلي من الظلمٍ ما أبقى لنا ذمما ويلي من الناسِِ كم ظالمٍ عبدوا(87).

و جرار بعد تتاول صفات الرجال الصادقين الأوفياء يترك قفلة القصيدة قصيدةً جديدة، إذ يقول:

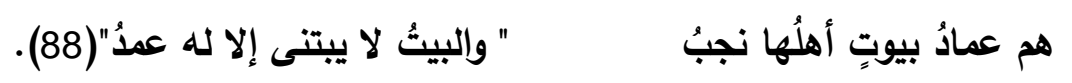

$$
\text { وهو مستمد من قول الثاعر الأفوه الأودي: }
$$

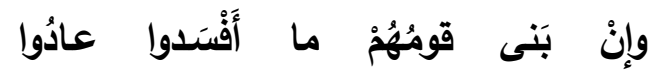

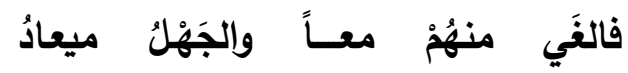

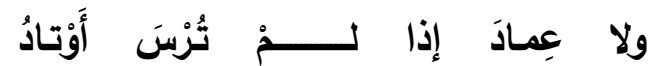

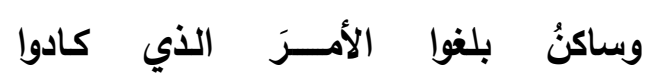

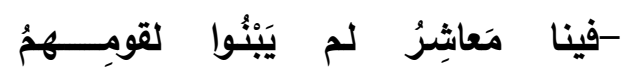

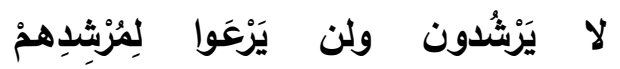

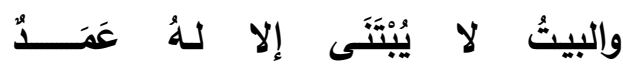

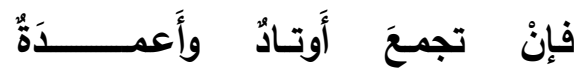

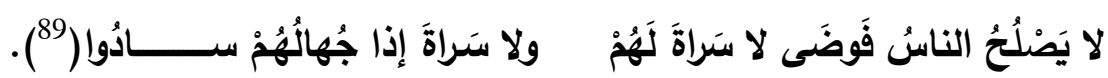

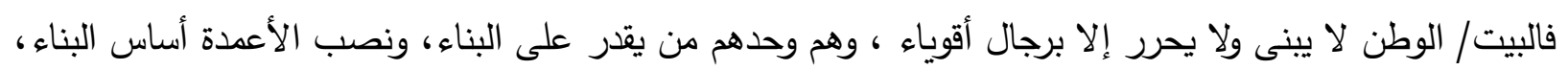

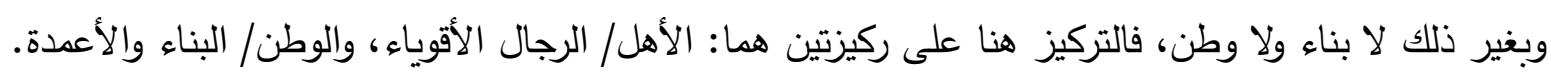

(84) جرّار، صلاح، في طريقي إليك، سابق، ص:23.

(86) (85) السابق نفسه، صنار:

(86) أبو تمام، ديوان أبي تمام بشرح الخطيب التبريزي.231هـه، تحقيق محمد عبده عزام، المجلد الأول. ط5. دار دار المعارف القاهرة. مصر ، ص:40.

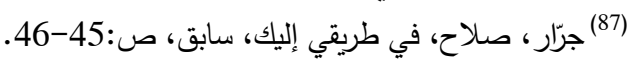

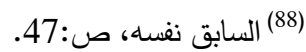

(89) الأودي، الأفوة، ديوان الأفوة الأودي،555هـ، شرح وتحقيق د. محمد التوتنجي. ط1. دار صادر للطباعة والنشر . بيروت.لبنان، 1998، ص:64. 


\section{الخاتمة}

تبين لنا من خلال هذا البحث أهمية العودة إلى الموروث في الخطاب الثعري عند الثعراء المحدثن

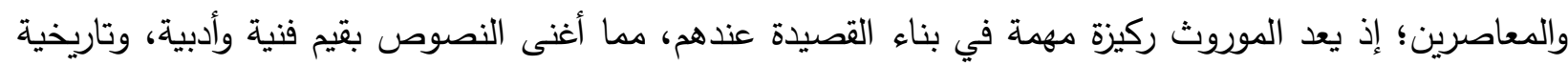

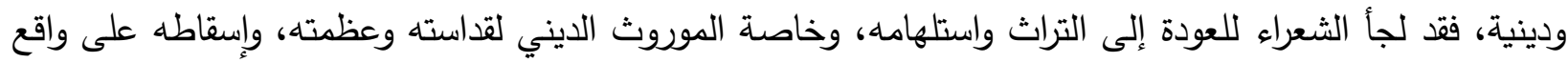
الأمة المليء بالهزائم والنكبات، فاستمدوا الآمال بالنصر ، وتحقيق ما تهفو إليه الأمة، من خلال موروثها العظيه.

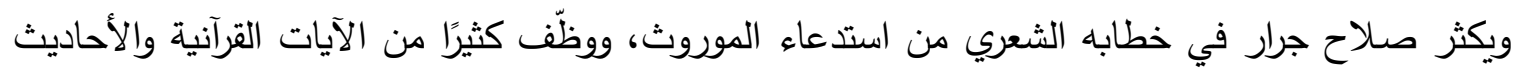
النبوية، والنصوص الثعرية والثخصيات التراثية، فكان البحث في محاور مهمة منها أثر القرآن الكريم والحديث النبوي

$$
\text { الثريف والثخصيات في شعر صلاح جرار . }
$$

إنَّ جرارًا استلهم النص التراثي قرآنًا وحديثًا وشعرًا في النص والعنوان والخاتمة، واهتََّّ بالعنونة التراثية المعتدةد

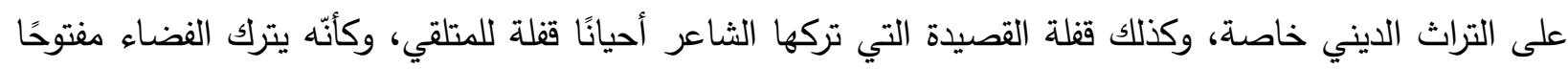
أمام المتلقي في آخر ما يقرع سمعه، ويشركه في قراءة النص.

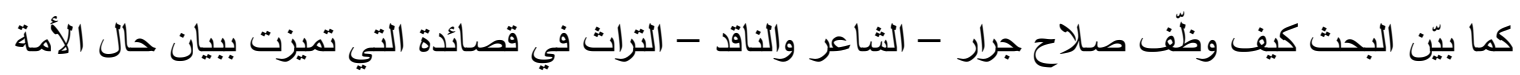

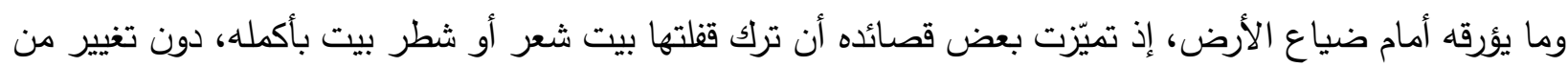

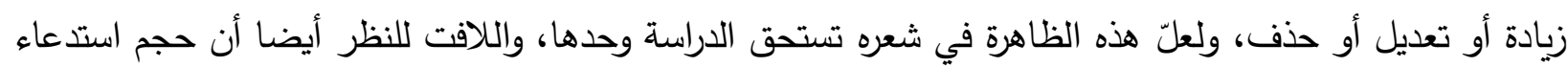

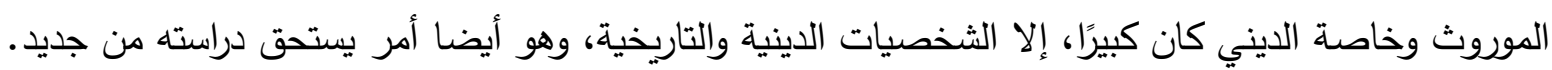

قائمة المصادر والمراجع

القرآن الكريم

أولا: الكتب

الأودي، الأفوة.( 1998). ديوان الأفوة الأودي، شرح وتحقيق د. محمد التوتجي. ط1. دار صادر للطباعة والنشر. بيروت لبنان. بلحاج، كاملي،(2004). أثر التراث الثعبي في تثكيل القصيدة العربية المعاصرة (قراءة في المكونات والأصول). اتحاد الكتاب العرب. دمشق. سوريا. أبو تمام، ديوان أبي تمام بشرح الخطيب التبريزي. تحقيق محمد عبده عزام. المجلد الأول. ط5. دار المعارف القاهرة. مصر جرّار ، صلاح.(2017). في طريقي إليك. ط1. الآن ناشرون وموزعون.عمان. جعافرة، ماجد.(2003). التتاص والتلقي، دراسات في الشعر العباسي. دار الكندي للنشر والوزيع. الأردن. 
ربابعة، موسى.(2000). التتاص في نماذج من الثعر العربي الحديث. ط1. إربد. الأردن، مؤسسة حمادة للدراسات الجامعية والنشر والتوزيع.

الرماني، إبراهيم.(1991). الغموض في الثعر العربي. ديوان المطبوعات الجامعية. ساحة بن عكنون. الجزائر . زايد، علي عشري.(1997). استدعاء الثخصيات التراثية في الثعر المعاصر . ط1. دار الفكر العربي. القاهرة. الزعبي، أحمد.(2000). التتاص نظريًّا وتطبيقيًّا. مطبعة الكتاني. إربد- الأردن. الزواهرة، ظاهر •(2008). اللون ودلالاته في الشعر ، الشعر الأردني نموذجًا. ط1. دار الحامد للنشر والتوزيع. عمان. الزواهرة، ظاهر ـ(2013). التناص في الثعر العربي المعاصر التتاص الديني نموذجًا. ط1. دار الحامد للنشر والتوزيع. عمان - الأردن. (- مان.

زهير ، كعب بن زهير •(1997). ديوان كعب بن زهير ، حققه وشرحه وقدم له الأستاذ علي فاعور • دار الكتب العلمية.

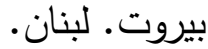
السعافين، إبراهيم.(1981). مدرسة الإحياء والتراث، دراسة في أثر الثعر العربي القديم على مدرسة الإحياء في مصر . ط4. بيروت- دار الأندلس. الثابي، أبو القاسم. ديوان أبي القاسم الثابي، أغاني الحياة. شرحه وضبط نصوصه وقدم له الدكتور عمر فاروق الطباع. دار القلم للطباعة والنشر • بيروت - لبنان. ابن شداد، عنترة.(1970). ديوان عنترة. تحقيق ودراسة محمد سعيد مولوي. المكتبة الإسلامية.

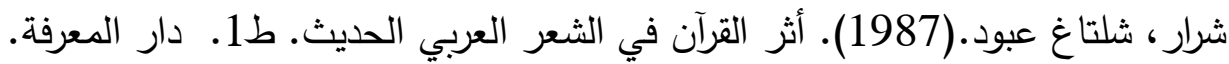
شوقي، أحمد.(2012). الثوقيات. مؤسسة هنداوي للتعليم والثقافة. القاهرة. مصر . ضيف، شوقي.(1960).العصر الجاهلي. ط8. دار المعراف. القاهرة. عبد الصبور، صلاح. (1992). الأعمال الكاملة( أقول لكم عن الشعر). الهيئة المصرية العامة للكتاب. القاهرة. العلاق، علي جعفر.(2002).الدلالة المرئية. ط1، دار الثؤون الثقافية العامة، بغداد. قطّوس، بسام.(1997). تجليات اللغة، قراءة نقدية في شعر إبراهيم الخطيب.ط1.وزارة الثقافة. المفرق.

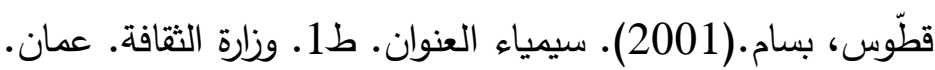
القيرواني، ابن رشيق.(1955).العمدة في محاسن الشعر ونقده.ج1. تحقيق:محمد مجيي الدين عبد الحميد. القاهرة. ابن كثير، إسماعيل بن عمر بن كثير القرشي أبو الفداء. البداية والنهاية. ج7. مباركي، جمال،(2007). التناص وجمالياته في الثعر الجزائري المعاصر • إصدارات رابطة الإبداع الثقافية، الجزائر . موسى، إبراهيم نمر،(2005). آفاق الرؤية الشعرية، دراسات في الشعر الفلسطيني المعاصر . ط1. جامعة بيرزيت: الهيئة العامة للكتاب. وزارة الثقافة. نواس، أبي نواس.(2010). ديوان أبي نواس، تحقيق الدكتور بهجت عبد الغني الحديثي. هيئة أبو ظبي للثقافة والتراث. دار الكتب الوطنية. 
ثانيا: الدوريات وإلمجلات

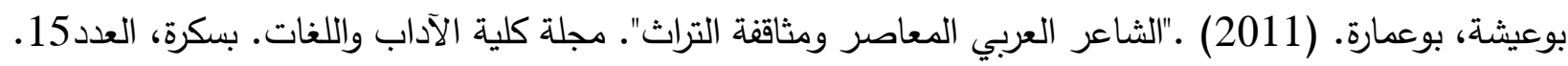

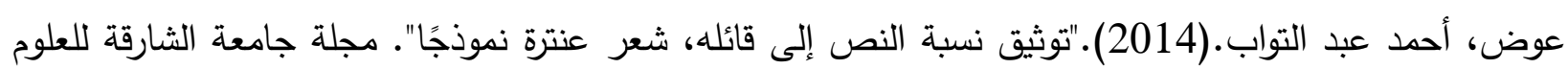
الإنسانية والاجتماعية.العدد2. المجلد 11. الكوفحي، إبراهيم.(2001). "توظيف الموروث الديني في شعر حيدر محمود". دراسات العلوم الإنسانية والاجتماعية. العدد الأول. المجلد 28. 